\title{
ANÁLISIS TÉCNICO - JURÍDICO DE LA MODALIDAD DE COBERTURA POR RECLAMACIÓN O “CLAIMS MADE” EN LOS SEGUROS DE RESPONSABILIDAD CIVIL A LA LUZ DEL ORDENAMIENTO JURÍDICO COLOMBIANO*
}

\section{TECHNICAL AND LEGAL ANALYSIS OF CLAIMS MADE SYSTEM FOR LIABILITY INSURANCES UNDER COLOMBIAN LEGAL FRAMEWORK}

\author{
Nicolás Uribe Lozada** \\ Fecha de recepción: 16 de mayo de 2016 \\ Fecha de Aceptación: 24 de mayo de 2016 \\ Disponible en línea: 30 de Julio de 2016
}

\section{Para Citar este articulo/To cite this article}

Uribe Lozada, Nicolas, Análisis técnico - jurídico de la modalidad de cobertura por reclamación o "Claims made" en los seguros de responsabilidad civil a la luz del ordenamiento jurídico colombiano, 44 Rev.Ibero-Latinoam.Seguros, 13-89 (2016). http://dx.doi.org/10. 11144/Javeriana.ris44.atjm

doi:10.11144/Javeriana.ris44.atjm

* El presente artículo de reflexión, es fruto de la maduración de la investigación realizada por el Autor sobre las cláusulas claims, desde que cursara la Maestría de Derecho de Seguros de la Pontificia Universidad Javeriana, nutrido por su experiencia profesional al haberse desempeñado durante varios años como intermediario de reaseguros, siempre bajo la sapiencia y orientación del doctor Bernardo Botero Morales

** Abogado egresado de la Pontificia Universidad Javeriana. Especialista y magíster de derecho de seguros de la misma Universidad. Miembro y Secretario Ejecutivo de la Asociación Colombiana de Derecho de Seguros Acoldese. Profesor universitario de pregrado y posgrado en la Universidad Javeriana (Especializaciones de Seguros y Comercial) y de posgrado en la Universidad Externado de Colombia en la Especialización de Seguros. Trabajó en la Compañía Central de Seguros (Hoy QBE Seguros) y posteriormente en Aon Benfield Colombia Corredores de Reaseguros por más de 10 años. Hoy en día es abogado independiente, socio fundador de Uribe Abogados consultores en seguros y reaseguros. Contacto: nicolas.uribe@uribeabogados.co 


\section{RESUMEN}

El presente escrito pretende realizar un análisis, tanto técnico como jurídico, fundado en la experiencia del mercado de seguros colombiano, las posiciones sentadas por la doctrina y la jurisprudencia y, particularmente el texto de los clausulados actualmente dispuestos por las compañías de seguros, de la operatividad del sistema de cobertura por reclamación hecha o "claims made", identificando sus falencias, sus bondades y sus elementos fundamentales, sin caer en la tentación de entrar en apasionamientos o posiciones radicales, que busquen defenderlo o atacarlo.

Además de revisar la configuración del siniestro y el cómputo del término de prescripción, se hace un sucinto repaso de sus antecedentes históricos de este sistema y, sus diferentes tipologías, haciendo igualmente, mención a algunos puntos polémicos como, la desprotección del asegurado, y la declaración del estado del riesgo, particularmente en tratándose de seguros colectivos o de grupo.

Palabras clave: Seguro de responsabilidad; modalidad por reclamación; sistema claims made; configuración del siniestro; delimitación temporal de la cobertura. 


\section{ABSTRACT}

This paper aims to make an analysis, both technical and legal, based on Colombian insurance market experience, positions granted by the doctrine and jurisprudence and particularly wordings currently offered by insurance companies, about the operation of the claims made system, identifying its flaws, its benefits and its fundamental elements, without falling into the temptation to enter infatuation or radical positions, seeking to defend it or attack it.

In addition to reviewing the configuration of the loss and rights time limitations, there will be a brief review of the historical background of this system and its typology, doing likewise mention of some controversial points such as the lack of protection of the insured, and declaration of a state of risk, particularly in the case of collective or group insurances.

Key words: Liability insurance; claims made clauses; loss configuration; temporal delimitation of coverage. 


\section{SUMARIO}

INTRODUCCIÓN. 1. LA REGLA GENERAL - SEGUROS DE RESPONSABILIDAD CIVIL POR OCURRENCIA PURA. 2. EXCEPCIONES A LA REGLA GENERAL ESTABLECIDAS en la Ley 389 de 1997. 3. Seguros por ReClamación o "Claims made". 3.1. Origen y necesidad de las pólizas "claims made". 3.2. ¿En los seguros por reclamación o "claims made" se modifica la definición clásica de siniestro para el seguro de responsabilidad civil en Colombia? 3.3. Modalidades existentes de "claims made", con coberturas retroactivas y ultractivas o prospectivas. 3.3.1. "Claims made" puras (sin periodo de retroactividad). 3.3.2. "Claims made" con retroactividad. 3.3.3. "Claims made" con coberturas prospectivas. 3.3.3.1. Periodo Extendido de Reporte o Adicional para Notificaciones. 3.3.3.2. Notificación de Hechos o Circunstancias que pudieran dar lugar a un reclamo. 3.4. Las formas prospectivas de amparo son un elemento connatural a los seguros bajo la modalidad "claims made". 3.5. Las cláusulas "claims made" zanjan cualquier discusión en torno a la póliza que debería afectarse en aquellos casos en los cuales la realización del hecho dañoso no coincide con la producción y manifestación del daño. 3.6 La desprotección del consumidor (tomador y asegurado) y de las víctimas pues sin lugar a dudas se trata de un esquema de aseguramiento más restrictivo que el tradicional por ocurrencia pura. 3.7. Declaración del estado del riesgo en los seguros de responsabilidad bajo la modalidad claims made - Exclusión de hechos y circunstancias previamente conocidas.4. CONFIGURACIÓN DE SINIESTRO EN LOS SEGUROS DE RESPONSABILIDAD CIVIL Bajo La modalidad Claims made.4.1. Definición de reclamo. 4.2. Notificación o reporte de la reclamación al asegurador. 4.3. Notificación de hechos y circunstancias conocidas durante la vigencia de la póliza de las cuales pudiera derivarse razonablemente a futuro una reclamación ¿Se modifica la definición del siniestro en los seguros "claims made"?. 4.4. Cláusula de unidad de reclamo. 4.5. Momento en el que se verifica el siniestro - notificación de la reclamación al asegurado.5. PRESCRIPCIÓN DE LA OBLIGACIÓN INDEMNIZATORIA EN LOS SEGUROS "CLAIMS MADE" O POR RECLAMACIÓN. 5.1. Prescripción de las acciones a favor del asegurado y del beneficiario del seguro de responsabilidad civil en contra de la aseguradora bajo el sistema "claims made". 5.2. El cómputo del término prescriptivo en los eventos en que se hubiese efectuado la notificación de hechos y circunstancias que podrían derivar en una reclamación futura. Bibliografía. 


\section{INTRODUCCIÓN}

Uno de los aspectos más interesantes y controvertidos de los seguros de responsabilidad civil, en la literatura jurídica, es la forma o base de cobertura empleada, pues bajo las legislaciones de muchos países, entre ellos Colombia, es posible ofrecer a los tomadores y asegurados, modalidades diferentes de operatividad del seguro. Específicamente, en nuestro país, pueden comercializarse seguros de responsabilidad bajo una modalidad por ocurrencia pura, ${ }^{1}$ ocurrencia con cláusula "sunset" ción hecha, mejor conocida por su nombre en inglés, "claims made".

El presente estudio tendrá como único propósito, realizar un análisis detallado, ecuánime, tanto técnico como jurídico, ajeno a apasionamientos doctrinales, sobre la forma de cobertura por reclamación hecha o "claims made”. Repasando sus antecedentes históricos, sus diferentes tipologías, algunas ventajas, desventajas y las principales implicaciones y consecuencias prácticas, en el día a día del negocio, incluyendo por supuesto, una mención en torno a la configuración del siniestro bajo esta modalidad y el cómputo de los términos de prescripción ante la compañía de seguros.

Iniciemos entonces en el análisis de las diferentes modalidades de cobertura que se ofrecen hoy en día para los seguros de responsabilidad civil en Colombia, empezando por la modalidad clásica de ocurrencia, para llegar a la nueva modalidad por reclamación o "claims made".

\section{LA REGLA GENERAL - SEGUROS DE RESPONSABILIDAD CIVIL POR OCURRENCIA PURA}

La regla clásica de delimitación temporal de los riesgos asegurados ha estado siempre marcada por la condición fundamental, y a la vez tácita, de que el siniestro, entendido como el acaecimiento de un hecho dañoso que daba lugar al surgimiento de un débito indemnizatorio a cargo del asegurado, tuviera lugar durante la vigencia de la póliza de seguro de responsabilidad. De tal manera, sólo se otorgaba cobertura, por parte de la compañía de seguros, si el hecho futuro e incierto del cual se desprendía un daño o una lesión física para la víctima, ocurría o tenía lugar durante la vigencia de la póliza expedida. Por consiguiente, los

1 Dicho mecanismo ha sido el tradicional de operación del seguro de responsabilidad y hasta el año 1997 fue el único legalmente permitido en nuestra normatividad.

2 En el presente estudio por razones de extensión no se abordará el estudio de esta modalidad. 
hechos que ocurrían antes del inicio de vigencia de la póliza y los que se producían con posterioridad a la terminación de la misma, carecían totalmente de cobertura o amparo.

Conforme el criterio general de cobertura con base en la ocurrencia, en tratándose de riesgos paulatinos, es decir, de aquellos que necesitaban del transcurrir del tiempo para su efectiva consolidación, se estableció en el artículo $1073^{3}$ del Código de Comercio, que no tendrían cobertura, cuando empezaran a desarrollarse antes del comienzo de la vigencia de la póliza, así consolidaran sus efectos durante la vigencia de esta. Por el contrario, los riesgos que comenzaran su desarrollo con posterioridad al inicio de vigencia la póliza y que consumaran sus efectos, incluso expirada la misma, sí contarían con cobertura, pues lo que marcaba la activación del seguro, era el punto de inicio de la realización del riesgo asegurado y no la fecha de su consumación.

En materia de responsabilidad civil, la realización del riesgo asegurado, ha sido siempre considerada por la doctrina como un hecho notablemente complejo, de muy difícil ubicación temporal, en cuanto al momento preciso de su realización. Esta circunstancia, ocasionó que fueran formuladas múltiples teorías en aras de determinar cuándo debería entenderse verificado el riesgo en los seguros de responsabilidad $\mathrm{y}$, por consiguiente, cuando se entendía producido el siniestro que daba origen a la obligación indemnizatoria a cargo del asegurador.

Con relación a este tema los profesores Ordóñez y Díaz-Granados ${ }^{5}$,

3 CÓDIGO DE COMERCIO. "Artículo 1073. < Responsabilidad del asegurador según el inicio del siniestro $>$. Si el siniestro, iniciado antes y continuado después de vencido el término del seguro, consuma la pérdida o deterioro de la cosa asegurada, el asegurador responde del valor de la indemnización en los términos del contrato. Pero si se inicia antes y continúa después que los riesgos hayan principiado a correr por cuenta del asegurador, este no será responsable por el siniestro."

4 En adición a las dos teorías principales mencionadas, el profesor Andrés Ordóñez afirma igualmente la existencia de las denominadas: c) la teoría de la liquidación de la deuda que aporta poco al debate al sostener que solo existirá una deuda de responsabilidad civil en el patrimonio del asegurado cuando se haya cuantificado una suma de dinero líquida; d) la teoría del pago que indica que solo habrá siniestro cuando el asegurado haya pagado a la víctima la indemnización a que hubiere lugar, teoría que no solo aporta poco al estudio sino que también condenaría al seguro de responsabilidad civil a ser un simple instrumento del rembolso, desconociendo de paso la existencia de la acción directa de la víctima contra el asegurador consagrada en varios ordenamientos jurídicos y; e) teoría del hecho complejo que indica que si la responsabilidad civil se configura en forma compleja (causa, daño, reclamación, liquidación y pago) igual acontecerá con el siniestro en el seguro de responsabilidad civil. ORDÓÑEZ ORDÓÑEZ, Andrés E. El contrato de seguro. La ley 389 y 1997 y otros estudios. Bogotá D.C. Universidad Externado de Colombia. 1998. p. 87-94.

5 DÍAZ-GRANADOS. Juan Manuel. El seguro de responsabilidad. Bogotá D.C. Editorial Universidad del Rosario y Pontificia Universidad Javeriana, Facultad de Ciencias Jurídicas. $2^{\circ}$ Edición. 2012. p. 149 - 155. El profesor Díaz-Granados igualmente destaca la existencia de las teorías de la liquidación de la deuda, del pago y la del hecho complejo. 
cada uno por su cuenta, destacan en sus obras, principalmente, la existencia de dos teorías fundamentales que intentan explicar dicho fenómeno a saber: a) la teoría del hecho dañoso y; b) la teoría del reclamo de la víctima, teoría esta última, que choca de plano con la modalidad de seguros por ocurrencia, pero que, como se revisará más adelante, encuadra perfectamente en el espectro de los denominados seguros por reclamación o "claims made".

Según la teoría del hecho dañoso, el siniestro se configura cuando se verifica físicamente una conducta pasiva o activa imputable al asegurado que lo hace civilmente responsable ante la víctima, es decir cuando acaece o tiene lugar el denominado "hecho dañoso", independientemente del momento en que se produzca la reclamación de dicha responsabilidad por parte de la víctima, la liquidación de la obligación indemnizatoria a cargo del civilmente responsable o el pago efectivo de dicha obligación para resarcir los perjuicios producidos. ${ }^{6}$

Como bien manifiesta el profesor Díaz-Granados: "La tesis del hecho dañoso cuenta con un sinnúmero de seguidores en la doctrina nacional e internacional, apoyados en textos legales que vinculan la noción de riesgo asegurado al hecho generador de la responsabilidad civil. Propugnan por una unión muy estrecha de las dos instituciones, de suerte que el seguro proteja al asegurado cuando surja la responsabilidad; es decir, en el momento en que acaezca el hecho y que dicha protección del seguro lo acompañe todo el tiempo durante el cual el agente del hecho esté expuesto a dicha responsabilidad". ${ }^{7}$

Bajo la teoría del hecho dañoso, la compañía de seguros se encontrará obligada a indemnizar el siniestro, ya fuere al asegurado o a la víctima beneficiaria del seguro, desde el momento mismo en que se verifique la conducta activa y omisiva del asegurado causante de perjuicios, cesando su responsabilidad, solamente cuando se haya verificado el fenómeno de la prescripción extintiva, ya fuere, la prescripción del derecho o acción de responsabilidad civil en cabeza de la víctima para requerirle al asegurado civilmente responsable la indemnización de los

$6 \quad$ Al respecto opina el doctor Andrés Ordóñez. "Sin duda la opción que más visos de acierto tiene es la que hace consistir el siniestro con la realización del hecho dañoso, pues la verdad es que ese hecho es el que genera débito de responsabilidad, dado dentro de las circunstancias que legalmente la constituyen; no es el reclamo, ni la liquidación del siniestro ni mucho menos la sentencia del juez; en cuanto al pago efectivo de la indemnización, solamente implica la realización final de la afectación patrimonial del asegurado”. Op. Cit. p. 97 
perjuicios producidos o, la prescripción de las acciones u obligaciones derivadas del contrato de seguros ante la compañía aseguradora ${ }^{8}$.

Con el ánimo de ser más precisos, es importante mencionar que algunos doctrinantes, muy destacados del derecho de seguros, aclaran que, al ser el interés asegurable del seguro de responsabilidad, la protección como un todo del patrimonio del asegurado, en rigor, sólo cabe hablar de siniestro cuando se produce el nacimiento de una deuda de responsabilidad a su cargo. En ese sentido, señala el profesor Donati que “(...) resulta correcto, identificar el siniestro con el nacimiento del débito de responsabilidad: constituye ciertamente una disminución del patrimonio neto, es decir, un daño". 9

En una línea similar, el profesor Sánchez Calero manifiesta que sería jurídicamente correcto aceptar que podrían coincidir en un mismo momento, el nacimiento de un débito de responsabilidad en el patrimonio de asegurado y el acaecimiento del hecho dañoso: “(...) si admitimos, siguiendo la doctrina general de la responsabilidad civil, que el nacimiento de la deuda de indemnización se produce de forma inmediata cuando se verifica el hecho dañoso (acción u omisión, o incumplimiento del contrato) del que se deriva esa deuda, de forma que el hecho dañoso es la causa del siniestro que precisamente es el nacimiento de la deuda de Responsabilidad Civil, habremos de admitir que es a partir del momento en que producido ese hecho surge la deuda de responsabilidad y el patrimonio del Asegurado se ve gravado por dicha deuda, lo que da lugar al daño. Desde esta perspectiva, nos parece que ha de concluirse que el siniestro en el Seguro de Responsabilidad Civil coincide con el nacimiento de la deuda generada por el hecho dañoso". ${ }^{10}$

La legislación colombiana, desde la versión inicial del Código de Comercio del año 1971 y su posterior modificación por la Ley 45 de 1990, acogió la tesis del hecho dañoso. El artículo $1131^{11}$ dispuso, que

8 Es pertinente recordar que del contrato de seguro de responsabilidad se desprenden dos acciones independientes y simultáneas ante la compañía de seguros, a saber, la acción directa en beneficio de la víctima contra el asegurador y la acción en cabeza del asegurado contra su asegurador para solicitar el pago de la indemnización a que hubiere lugar a favor de la víctima o el rembolso de lo que ya hubiera indemnizado previamente el asegurado al afectado.

9 DONATI, Antígono. Los seguros privados. Barcelona. Bosch.1960. p. 401.

10 SÁNCHEZ CALERO, Fernando. La delimitación temporal del riesgo en el seguro de responsabilidad civil tras la modificación del artículo 73 de la Ley de contrato de seguro" En: Revista Española de Seguros, núm. 89, de 1997. p. 14.

11 CÓdIGO DE COMERCIO. “Artículo. 1131. Ocurrencia del siniestro. Modificado. Ley 45 de 1990, 
se entiende ocurrido el siniestro en el momento en que acaezca el hecho externo imputable al asegurado. En desarrollo del artículo 1131, la Corte Suprema de Justicia, en su Sala de Casación Civil terminó acogiendo la tesis del débito de responsabilidad, mediante sentencia del 10 de febr

ero de 2005, exp. 7614 en la que manifestó: “(...) el surgimiento de una deuda de responsabilidad a cargo de aquel [el asegurado] es lo que determina el siniestro en esta clase de seguro".

Como se ha comentado, habrá realización del riesgo asegurado y, por ende, siniestro a la luz de los seguros de responsabilidad civil clásicos por ocurrencia, cuando se verifique el nacimiento de un pasivo en el patrimonio del asegurado, es decir, sí, y sólo sí, durante la vigencia de la póliza se verifican tanto un hecho dañoso realizado por el asegurado, un nexo de causalidad y un perjuicio generado a otro sujeto, perjuicio que, como será visto, podrá manifestarse en forma inmediata o con el paso de los años, pero, en todo caso, deberá ser consecuencia directa del hecho dañoso incurrido por el asegurado una vez iniciada la vigencia de la póliza.

Partiendo de la base de que el siniestro corresponde al acaecimiento del hecho dañoso, es menester, distinguir dos momentos marcadamente diferentes, el primero, aquel relativo a la ocurrencia del siniestro que estará señalado por el acaecimiento del hecho externo imputable al asegurado, que por cierto será el elemento o requisito constitutivo o de existencia de cobertura en el seguro de responsabilidad contratado. Y un segundo momento, que corresponderá a la reclamación que formule la víctima al asegurado que, para los efectos del contrato de seguro de responsabilidad bajo la modalidad por ocurrencia, marcará únicamente requisito de mera exigibilidad y, por ende, supeditará el inicio del cómputo del término de prescripción de las acciones derivadas del contrato de seguro otorgadas a favor del asegurado. ${ }^{12}$

Para finalizar la referencia a los seguros por ocurrencia y a la denominada teoría del hecho dañoso, es importante mencionar que no todo es armónico, ni está libre de polémica. La doctrina ha identificado principalmente dos falencias, a saber en esta modalidad o forma de cobertura: a) se deja de lado que no habrá una verdadera obligación

Art. 86. "En el seguro de responsabilidad se entenderá ocurrido el siniestro en el momento en que acaezca el hecho externo imputable al asegurado, fecha a partir de la cual correrá la prescripción respecto de la víctima. Frente al asegurado ello ocurrirá desde cuando la víctima le formula la petición judicial o extrajudicial".

12 DÍAZ-GRANADOS. Op. Cit. p. 175 - 176. 
indemnizatoria por parte del asegurador hasta tanto la víctima reclame la indemnización de sus perjuicios al asegurado o directamente al asegurador y; b) No siempre el daño se configura de manera inmediata, es decir en muchas ocasiones existe un amplio periodo de latencia entre el acaecimiento del hecho activo u omisivo y la manifestación o floración del daño. Ello sucede principalmente en los denominados daños diferidos o tardíos.

Con relación a la primera salvedad formulada expresaba el profesor Joaquín Garrigues: "El siniestro en el seguro de responsabilidad civil, es un siniestro que no se produce en un solo hecho, sino en una sucesión de hechos. Es un siniestro en desarrollo sucesivo que comienza con el hecho culposo causante del daño. La Ley del seguro ha considerado siniestro precisamente ese hecho inicial, aunque hay que reconocer que el verdadero siniestro no se produce hasta tanto se reclame la correspondiente reparación por la víctima del daño". ${ }^{13}$ En otras palabras, es un contrasentido hablar de siniestro a cargo del asegurador por la simple ocurrencia de un hecho dañoso porque en últimas solo será la reclamación de la víctima la que hará efectiva la afectación del seguro.

En lo que respecta a los denominados daños diferidos o tardíos, su innegable existencia ha llevado a la doctrina a preguntarse, sin que se haya logrado un consenso sobre el particular, cuándo debía entenderse generado el débito de responsabilidad a cargo del asegurado: si en el momento en que se produjo el hecho dañoso, cuándo se manifestó o afloró el daño o cuándo se verificó la petición indemnizatoria por parte de la víctima. Siendo claro que la solución que se escogiere no sería de poca monta, dado que la misma, marcaría el señalamiento o escogencia de una única póliza de seguro de responsabilidad civil que ampararía el evento dañoso y la fecha a partir de la cual se daría inicio al cómputo de los términos de prescripción extintiva.

Ha sido precisamente, la dificultad práctica, por no decir que virtual imposibilidad de determinar cuál debería ser la póliza de seguro afectada cuando se presentaban daños tardíos o diferidos, una de las varias razones que llevaron a que el mercado de seguros y reaseguros formu-

13 GARRIGUES, Joaquín. Contrato de Seguro Terrestre. Segunda edición. Madrid. Imprenta Aguirre. 1.983.p. 375. 
laran un nuevo sistema o base de cobertura para amparar la responsabilidad civil, el esquema por reclamación o "claims made"14.

\section{EXCEPCIONES A LA REGLA GENERAL ESTABLECIDAS EN LA LEY 389 DE 1997}

En 1997, se expide en Colombia la Ley 389 con el ánimo de mutar la forma del contrato de seguro, dejando atrás su carácter solemne para adoptar un criterio eminentemente consensual, acorde con el tráfico mercantil moderno. El sector asegurador, aprovechando esa oportunidad legislativa y, siguiendo en buena medida la experiencia española y, en general, la tendencia mundial, logró que en el artículo cuarto ${ }^{15}$ de la Ley se permitiera oficialmente el uso en Colombia de seguros con base de cobertura por reclamación y por descubrimiento. ${ }^{16}$

Sobre el proceso de expedición de la Ley 389 de 1997, y en general sobre la génesis y motivos que gestaron la promulgación de la misma, es sumamente valioso traer a colación las reflexiones hechas por el profesor Bernardo Botero:

"Los ilustres juristas doctores Carlos Ignacio Jaramillo, Andrés Ordóñez y Juan Manuel Díaz-Granados son de la opinión de que la institución del seguro por reclamación o claims made surge en Colombia, por influencia de la Ley de Ordenación y Supervisión de los seguros Privados de España expedida en 1995. Sin dejar de reconocer, por supuesto, la influencia de la legislación española,

14 MIRANDA SUÁREZ, Francisco. Seguro de responsabilidad civil por mal praxis médica. Delimitación temporal de la cobertura del Seguro. En: Revista Ibero-Latinoamericana de Seguros. Número 16 de 2001. Bogotá D.C. Javegraf- Pontificia Universidad Javeriana Pág. 112.

15 CONGRESO DE LA REPÚBLICA. Ley 389 de 1997. "Artículo 4. En el seguro de manejo y riesgos financieros y en el de responsabilidad la cobertura podrá circunscribirse al descubrimiento de pérdidas durante la vigencia, en el primero, y a las reclamaciones formuladas por el damnificado al asegurado o a la compañia durante la vigencia, en el segundo, así se trate de hechos ocurridos con anterioridad a su iniciación. Así mismo, se podrá definir como cubiertos los hechos que acaezcan durante la vigencia del seguro de responsabilidad siempre que la reclamación del damnificado al asegurado o al asegurador se efectúe dentro del término estipulado en el contrato, el cual no será inferior a dos años. PARÁGRAFO. El Gobierno Nacional, por razones de interés general, podrá extender lo dispuesto en el presente artículo a otros ramos de seguros que así lo ameriten".

16 Es importante mencionar que la modalidad de seguros por descubrimiento que permite igualmente amparar hechos pretéritos había sido incorporada por primera vez en el país mediante la expedición de la Ley 35 de 1993, cuyo artículo 23 dispuso: "Riesgos de la actividad financiera. En los seguros que tengan por objeto el amparo de los riesgos propios de la actividad financiera, se podrán asegurar, mediante convenio expreso, los hechos pretéritos cuya ocurrencia es desconocida por tomador y asegurador". La norma del año 1993 tenía una redacción un tanto confusa y un alcance limitado únicamente al sector financiero, razón que justificó la nueva mención de esta modalidad en el artículo 4 de la Ley 389 de 1997. 
la verdad es que fue más la presión generada por los mercados internacionales de reaseguro que se negaban otorgar cobertura de responsabilidad civil para algunas actividades bajo el tradicional enfoque de "ocurrencia", o sea de que la cobertura se entienda otorgada bajo la póliza vigente en el momento en que se produzca el hecho generador de la responsabilidad, lo que motivó la necesidad de introducir el cambio legislativo en Colombia. Naturalmente, reiteramos, al consignarse en la legislación colombiana la cobertura bajo el sistema claims made, indudablemente se tomó como punto de referencia la, en ese entonces, recientemente expedida normatividad española a respecto.

Habida consideración de las manifiestas dificultades para la obtención de reaseguro o del elevado costo del mismo bajo la modalidad de "ocurrencia", las aseguradoras colombianas, a través de su entidad gremial FASECOLDA, aprovechando el trámite en curso ante el Congreso de la República del proyecto de ley mediante el cual se proponía la modificación de los artículos 1036 y 1046 del código de comercio, relativos al carácter solemne del contrato de seguro con miras a dotarlo de naturaleza consensual, propusieron la introducción de un artículo - en definitiva el artículo $4^{\circ}$ de la Ley 389 de 1197 - mediante el cual en su inciso primero se consagrase la viabilidad legal de los seguros claims made y de paso se hiciese más amplia la viabilidad legal de cobertura bajo en concepto de "descubrimiento", para los riesgo propios de la las pólizas de manejo y riesgos financieros, inicialmente limitada a los riesgos propios de la actividad financiera por el artículo 23 de la Ley 35 de 1993.

No está por demás poner de presente que en Colombia la introducción del sistema de aseguramiento claims made o "por reclamación" - como también del sistema de aseguramiento "por descubrimiento" regulado inicialmente, como se anotó, por el artículo 23 de la Ley 35 de 1993 - requirió de la expedición de norma legal, en razón de la expresa imposibilidad del otorgamiento de una modalidad de cobertura distinta a la de seguro "por ocurrencia" de conformidad con lo dispuesto, entre otras normas, por el artículo 1054 del código de comercio, artículo mediante el cual, además de definirse el concepto de riesgo, se consigna la no asegurabilidad, por no constituir riesgo, del denominado riesgo putativo, o sea de la incertidumbre subjetiva sobre la ocurrencia o no de determinado hecho, asegurabilidad esta que, para ese entonces, estaba permitida únicamente, por vía de excepción, para los riesgos propios de la actividad marítima, al tenor de lo dispuesto por el artículo 1706 del código de comercio, norma por demás arcaica, dado el portentoso avance tecnológico de las comunicaciones". ${ }^{17}$

Los nuevos esquemas de cobertura incorporados en el año 1997, diametralmente diferentes, en su concepción, al tradicional mecanismo basado en la ocurrencia pura, admiten el amparo de hechos pretéritos, pues el detonante de la cobertura, en uno y en otro caso, será un

17 BOTERO MORALES, Bernardo. La teoría y la práctica del seguro por reclamación o seguro claims made. Ponencia presentada En: $1^{\circ}$ Congreso Internacional de Derecho de Seguros: La Protección del Consumidor y el Seguro de Responsabilidad Civil. Cartagena de Indias, marzo 22 y 23 de 2012. s.n.; s.p.i.; p. 2 y 3. 
hecho posterior a la producción del daño. En los seguros por descubrimiento será el conocimiento del asegurado de la pérdida ocurrida y, en los seguros por reclamación, precisamente la solicitud que le haga la víctima al asegurado o a la aseguradora para obtener la indemnización o reparación de los perjuicios sufridos.

Para que haya cobertura en un seguro de responsabilidad, a diferencia de lo que sucede por regla general tanto en los seguros de daños como en los de personas, no es indispensable que el riesgo asegurado, que ha sido señalado por la doctrina ${ }^{18}$ como el surgimiento de un débito en el patrimonio del asegurado consistente en la obligación de indemnizar los perjuicios causados a otra persona, se verifique necesariamente durante la vigencia de la póliza. De hecho, como será comentado más adelante, en los seguros por reclamación o con cláusula "claims made" el detonante de la cobertura, que en la práctica equivale al siniestro mismo o al surgimiento de la obligación indemnizatoria en cabeza de la compañía de seguros, se verifica con un hecho posterior al nacimiento del pasivo en el patrimonio del asegurado, consistente en la reclamación que la víctima formule ante el propio asegurado o ante su asegurador, en este último caso, en ejercicio de la acción directa consagrada por el artículo $1133^{19}$ del Código de Comercio.

En síntesis, en materia del seguro de responsabilidad civil, antes de la expedición de la ley 389 de 1997, el único sistema existente para delimitar temporalmente el riesgo era el de ocurrencia pura, sistema que hoy en día continúa siendo el más usado, tanto así que, de no mediar pacto expreso en contrario, será esta la modalidad imperante, sin perjuicio de que ahora perviva con las otras modalidades que fueron atrás reseñadas y que se revisarán por separado en las próximas líneas. ${ }^{20}$

18 Se destacan como como abanderados de esta posición, los profesores Antígono Donati y Fernando Sánchez Calero. DONATI, Antígono. Los seguros privados. Barcelona. Bosch.1960. p. 401. SÁNCHEZ CALERO, Fernando. La delimitación temporal del riesgo en el seguro de responsabilidad civil tras la modificación del artículo 73 de la Ley de contrato de seguro" En: Revista Española de Seguros, núm. 89, de 1997. p. 14.

19 CÓDIGO DE COMERCIO. “Art. 1133.- Modificado. Ley 45 de 1990, Art. 87. <Acción de los damnificados en el seguro de responsabilidad $>$. En el seguro de responsabilidad civil los damnificados tienen acción directa contra el asegurador. Para acreditar su derecho ante el asegurador de acuerdo con al artículo 1077, la víctima en ejercicio de la acción directa podrá en un solo proceso demostrar la responsabilidad del asegurado y demandar la indemnización del asegurador.'

20 Al respecto, el profesor Carlos Ignacio Jaramillo señala que a partir de la expedición de la Ley 389 de 1997 se presente en Colombia la pervivencia, como mínimo, de dos episodios siniestrales diferentes, uno para el sistema tradicional o convencional de ocurrencia pura y, otro, para el sistema extraordinario o moderno de reclamación, sistemas ambos edificados sobre bases y condiciones propias, que les permiten distinguirse de su antagonista. JARAMILLO JARAMILLO, Carlos Ignacio. Derecho de 


\section{SEGUROS POR RECLAMACIÓN O "CLAIMS MADE"}

A continuación, se hará una revisión detallada de los principales aspectos relacionados con el surgimiento, clasificación, efectos y consecuencias que se han generado en el mundo comercial y de los seguros, especialmente en Colombia, con ocasión de la incorporación y uso de dichas cláusulas en los seguros de responsabilidad civil.

\subsection{Origen y necesidad de las pólizas "claims made"}

Como se anticipó líneas atrás, el seguro bajo la modalidad de ocurrencia pura tenía serios problemas relacionados con el factor tiempo, en los denominados daños diferidos ${ }^{21}$, que generaban negativas consecuencias financieras para las compañías aseguradoras y reaseguradoras, pues la naturaleza y operatividad de este tipo de seguros, les obligaba a conservar durante largos periodos reservas de siniestros (tanto avisados como siniestros ocurridos pero no reportados IBNR), para hacer frente a futuras e hipotéticas reclamaciones, cargando de esa manera las compañías de seguros y reaseguros, con la costosa incertidumbre de desconocer si tendrían que efectuar o no dichas erogaciones. ${ }^{22}$

La adopción del sistema de seguro de responsabilidad civil por reclamación fue fruto de un dilatado proceso, corolario de las dificultades

Seguros. Tomo II. Bogotá D.C., Editorial Temis S.A.-Pontificia Universidad Javeriana. 2.011. Pág. 319.

21 Las dificultades operativas del esquema de ocurrencia pura cuando se producían daños diferidos es explicado por Juan Manuel Díaz-Granados, así: "El sistema de ocurrencia es aplicable sin mayores problemas para los daños instantáneos, dado que es fácil identificar el momento específico de la configuración del siniestro y de la respectiva póliza. Ello no ocurre así en los eventos de manifestación tardía por existir periodos de latencia o cuando, tratándose de daños instantáneos, la víctima reclama mucho tiempo después de la ocurrencia de los hechos, circunstancia cuya extensión es definida por los términos de prescripción de la responsabilidad civil establecidos en la ley." DÍAZ-GRANADOS. Op. Cit. p. 158.

22 Con relación a este aspecto afirma el profesor Andrés Ordóñez que uno de los problemas que se desprende de la circunstancia que en materia de seguros de responsabilidad pueda trascurrir un prolongado espacio de tiempo entre el momento del siniestro (adquisición de la deuda o producción del hecho dañoso) y el momento en que se pague esa deuda por parte del asegurador: es que este último: “... permanezca durante mucho tiempo en la incertidumbre sobre las sumas de dinero que tendrá que erogar eventualmente como consecuencia de su calidad de asegurador, lo cual implica: a) dificultad en la evaluación y control de las reservas técnicas de las aseguradoras; b) prolongación indefinida de la constitución de esas reserva, y c) mantenimiento de contratos en estado de suspensión, cuestión que a su vez puede depender de circunstancias de hecho, en el caso de los daños que se evidencian con mucha posterioridad a las conductas imputables al asegurado, y de derecho, cuando los plazos de prescripción de las acciones de las víctimas contra los asegurados son demasiado largos". ORDÓÑEZ. Op. Cit. Págs. 98-99. 
experimentadas por el sistema tradicional de ocurrencia, fincadas, especialmente, en los denominados riesgos de cola larga (long tail risk), es decir, aquellos ligados a los denominados daños tardíos o diferidos, a los extensos términos de prescripción consagrados en algunos ordenamientos jurídicos y a las cuantiosas pérdidas padecidas por la industria aseguradora durante los años ochenta como manifestación tardía y simultánea de varias patologías: asbestosis, talidomida, DES (diethylistibesterol) y el Agente Naranja. ${ }^{23}$

Las circunstancias mencionadas obligaron a que las compañías de seguros debieran mantener en suspenso durante muchos años sus prestaciones indemnizatorias a los asegurados o a las víctimas, pues, en numerosas ocasiones, las pólizas de seguros contratadas sólo se afectaban diez o veinte años después de haber expirado su vigencia, ya fuere porque la víctima dejaba siempre para el final la reclamación del perjuicio sufrido, aprovechando para ello los dilatados términos de prescripción extintiva consignados en muchos ordenamientos jurídicos, o simplemente porque en muchos casos, entre la generación del daño y su efectiva manifestación, podrían trascurrir varios años. ${ }^{24}$

23 El jurista español Eduardo Pavelek Zamora es elocuente a la hora de precisar el momento en que surgen históricamente los seguros de responsabilidad civil bajo la modalidad "claims made" como una alternativa válida para hacer frente al amparo de nuevas responsabilidades que no podían seguir siendo amparadas por viejas pólizas o productos: "En 1986 a la vista de los problemas de interpretación surgidos, especialmente en los casos del Asbestos, productos químicos, contaminación y especialidades farmacéuticas que generan daños latentes manifestados a lo largo de periodos de tiempo extraordinariamente dilatados, se formula una nueva redacción a las pólizas CGL (Commercial General Liability), introduciendo un nuevo esquema que sencillamente viene a significar que la cobertura del seguro se aplica solamente a aquellos supuestos en que la reclamación es formulada (made) durante el periodo de vigencia de la póliza. En realidad, no se trata de un sistema tan cerrado ya que, según cada actividad concreta, es posible estipular coberturas retroactivas o ampliar el plazo de las reclamaciones, aunque la póliza se haya extinguido, pero todo ello con recargos adicionales sobre las primas básicas" PAVELEK ZAMORA, Eduardo. Delimitación temporal en el seguro de responsabilidad civil la nulidad del "claims made" ¿otra vuelta a la tuerca? En: Gerencia de Riesgos, núm., 41. Fundación Mapfre Estudios. 1993. p.43.

24 En palabras de Francisco Miranda Suárez: "En el hecho, y como reacción a los problemas económicos y jurídicos generados por los siniestros tardíos, surgieron en 1984 en los Estados Unidos de América, las cláusulas Claims made, patrocinadas por la Insurance Services Organization buscando con ello limitar el periodo de cobertura de las pólizas por la vía de requerir que la reclamación debía producirse durante el periodo de vigencia de la póliza, con independencia de cuando haya ocurrido el hecho que lo genera, el hecho generador de responsabilidad. (...) Para poder entender la racionalidad de estos mecanismos de delimitación temporal de la cobertura, hay que considerar que el fundamento de estas cláusulas es más económico que jurídico, esto es, su razón de ser está en el mayor costo que significa tener que mantener durante el plazo de prescripción reservas técnicas inmovilizadas, y percibir una única prima. Las múltiples demandas con solicitud de cuantiosas indemnizaciones interpuestas en Estados Unidos en los históricos en los que se perseguía la responsabilidad civil, como lo fueron los casos de Asbestosis, Agente Naranja, DES y otros, con demandas interpuestas 20, 30 o más años después del hecho generador de responsabilidad, hicieron surgir la natural preocupación en el 
Todos los anteriores factores motivaron a que los mercados aseguradores y reaseguradores presionaran para que dichos productos fueran aceptados y comercializados en los diferentes lugares del mundo, siendo necesario en muchos sitios la promulgación de normas legales para hacer frente a la potente oposición liderada por la doctrina y la jurisprudencia. Conociendo su origen y formación, bien podrían calificarse los seguros de responsabilidad civil por reclamación como un "mal necesario" pues sin su presencia actualmente sería inviable la obtención de cobertura para ciertas formas de responsabilidad civil, como la responsabilidad civil profesional, bien fuere por falta de oferta de dicho producto o simplemente por un precio tan oneroso de la prima que lo haría simplemente inviable económicamente hablando. ${ }^{25}$

Con lo hasta aquí dicho, puede concluirse que las cláusulas "claims made" implican una delimitación temporal del ámbito de cobertura del seguro de responsabilidad civil, dirigida efectivamente a la eliminación de los costos financieros que representaban para las compañías aseguradoras la constitución indefinida de reservas de siniestros para los denominados riesgos de cola larga, es decir, para aquellos eventos que implicaban que un seguro de responsabilidad civil pudiera mantener efectos prospectivos por más de diez años después de su expiración natural. ${ }^{26}$

Revisada la génesis de los seguros de responsabilidad civil por reclamación o "claims made", es procedente ahora plantearse algunos in-

mercado asegurador internacional, La búsqueda de fórmulas para no mantener latente el riesgo por una demanda judicial durante todo el tiempo que dura la prescripción legal extintiva, se transformó en orden del día, y la cláusula Claims made, su hijo pródigo, permitiendo limitar temporalmente la cobertura de la póliza”. Op. Cit. p. 112-114.

JARAMILLO. Derecho de Seguros. t. II. Op. Cit. p. 327-336.

26 Con relación a lo anterior, es especialmente preciso el profesor Carlos Ignacio Jaramillo, quien afirma que las cláusulas "claims made" no son una delimitación causal del riesgo asegurado, como lo sería una simple exclusión, sino que consisten específicamente en una delimitación temporal del mismo: "Desde esta perspectiva es claro que entonces que el sistema de aseguramiento o de introducción negocial de las denominadas cláusulas "claims made" es el producto de la delimitación temporal de la cobertura o del amparo otorgado por el asegurador y no de la delimitación causal del riesgo asegurado; es corolario de una estipulación que concierne a la dimensión temporaria del seguro y no a la que cobija a las causas potenciales del siniestro vinculante, a voces el artículo 1056 del Código de Comercio nacional, según el cual, "Con las restricciones legales, el asegurador podrá, a su arbitrio, asumir todos o algunos de los riesgos a que estén expuestos el interés o la cosa asegurados, el patrimonio o la persona del asegurado" (...) Así las cosas, este nuevo esquema se traduce en un sistema de aseguramiento con arreglo al cual, ex ante, se delimita temporalmente el riesgo asegurado, en la medida en que se establece que la entidad aseguradora, inicialmente, responderá en aquellos casos en que la reclamación se presente durante la vigencia del seguro, todo en función de diversas modalidades o reglas especiales de cobertura, aún prospectivas (post-contractum). JARAMILLO. Ibídem. p. 321 - 322. En el mismo sentido se puede consultar a STIGLITZ Rubén. Temas Derecho de Seguros Bogotá. Grupo Editorial Ibáñez-Pontificia Universidad Javeriana. 2.010. p. 249 -250 
terrogantes con el ánimo de profundizar en torno a sus características y a las consecuencias técnicas y jurídicas que se verifican a partir de su existencia.

\title{
3.2 ¿En los seguros por reclamación o "claims made" se modifica la definición clásica de siniestro para el seguro de responsabilidad civil en Colombia?
}

\author{
El pensamiento mayoritario de los autores colombianos, entre los que \\ se destacan los doctores Maria Cristina Isaza Posse, Hilda Zornosa \\ Prieto, Jorge Eduardo Narváez Bonnet, Juan Manuel Diaz-Granados y \\ Carlos Ignacio Jaramillo, ${ }^{27}$ es que para los seguros de responsabilidad
}

27 Sobre el particular afirma María Cristina Isaza: "Hasta tanto no se presente la reclamación por parte de la víctima al asegurado o a la aseguradora no se puede entender ocurrido el siniestro, no se ha realizado el riesgo previsto en el contrato de seguro y no se ha cumplido la condición que hace exigible la obligación de la aseguradora. En consecuencia, los términos de prescripción empiezan a correr respecto de la víctima desde el momento en que se formula la reclamación." ISAZA POSSE, María Cristina. (2013) "Ámbito temporal de la cobertura y prescripción en el seguro de responsabilidad civil” Revista Ibero-Latinoamericana de Derecho de Seguros, número 22, Bogotá, Pontificia Universidad Javeriana, p 146

Por su parte Jorge Eduardo Narváez indica: "En otras palabras, en las coberturas claims-made, como el siniestro lo configura la reclamación que formula el afectado en contra del asegurado o de la compañía de seguros en virtud de la ocurrencia de un hecho dañoso, respecto del cual se predica que aquel es civilmente responsable, es evidente que se restringe la garantía del asegurador a los reclamos que se formulen durante la vigencia del amparo y por lo tanto, es eximido de reclamos que puedan tener un periodo de latencia prolongado con un efecto benéfico en sus provisiones para siniestros incurridos pero no reportados." NARVÁEZ BONNET, Jorge Eduardo. El Contrato de Seguro en el Sector Financiero. Grupo Editorial Ibáñez. Tercera Edición. 2014. p. 534.

En la misma línea la doctora Hilda Zornosa manifiesta: "En el llamado siniestro de reclamación puro se ha venido interpretando que, para esta nueva modalidad de amparo, hubo una derogatoria tácita del artículo 1131 del Código de Comercio; lo anterior, debido a que si bien allí se dice que el siniestro se configura con el hecho externo imputable al asegurado, la nueva Ley 389 de 1997 permite que el asegurador pueda otorgarle cobertura a los reclamos que se formulen durante la vigencia, así estos se fundamenten en hecho acaecidos antes de la iniciación de la misma." ZORNOSA PRIETO, Hilda. Los problemas de interpretación de la prescripción en el seguro de responsabilidad civil en la legislación colombiana bajo el sistema claims made. En: Escritos sobre riesgos y seguros. Universidad Externado de Colombia. 2012. P. 638.

Por su parte, el profesor Carlos Ignacio Jaramillo sostiene: "En este sistema extraordinario y particular, en el que usualmente media un recorte respecto a la cobertura o riesgo asegurado de cara al futuro, el fundamento cardinal de índole obligacional y, por contera, siniestral, finca en la reclamación del tercero, ya no como una teoría de raigambre doctrinal, jurisprudencial o, inclusive legal, sino como su ratio funcional, o sea, como su explicación genética y operacional. Ella, es cierto, sin desconocer la fuerza del hecho externo imputable, se constituye en el epicentro del esquema en comentario, en su núcleo, propiamente dicho, habida cuenta que todo lo determinante gira en torno a ella, ora directa, ora indirectamente, aun cuando es viable la combinación de modalidades, como se acotará, pero siempre en función del que descansa en la reclamación ("claims made"). El acento, en tal virtud, se hará pues en la reclamación, nervio de la reforma, hasta el punto que ellos es lo que denota en castellano el término sistema de reclamación, o en inglés, "claims made": "hecho el reclamo". 
civil con base en la reclamación o “claims made”, sí se modificó la noción clásica del siniestro, pues el detonante de la obligación dineraria a cargo de la aseguradora será ahora la reclamación que eleve el tercero al asegurado o al asegurador, sin que para el efecto tenga ya la misma relevancia el momento en que se haya verificado el hecho dañoso, bastando únicamente, que el mismo hubiere tenido lugar durante la vigencia de la póliza o con anterioridad al inicio de la misma, dentro del denominado periodo de retroactividad establecido.

Por ejemplo, Juan Manuel Díaz-Granados, afirma que la adopción del sistema "claims made" para los seguros de responsabilidad civil en Colombia implicó la redefinición del concepto siniestro establecido para el sistema clásico de ocurrencia, legislativamente consagrado en el artículo 1.131 del C.Co., que a su tenor establece que para los seguros de responsabilidad civil será siniestro la materialización o acaecimiento de un hecho dañoso. En sus palabras: "Si conforme el artículo $1.072 \mathrm{del}$ Código de Comercio siniestro es la realización del riesgo asegurado, es necesario concluir que la Ley 389 de 1997 en su artículo 4, inciso 1, modificó el concepto de siniestro para esta modalidad en particular. En otros términos, si con base en esta ley los contratantes pactaron que el riesgo asegurado se refiere a las reclamaciones presentadas durante la vigencia, para estos efectos habrá que entender modificado el artículo 1131 del Código de Comercio y, en consecuencia, concluir que el siniestro se presenta en el momento de la reclamación y no cuando acaezca el hecho externo imputable al asegurado". ${ }^{28}$

Sin reclamación (judicial o extrajudicial del tercero), se ha dicho, no sin alguna controversia, no habrá finalmente siniestro, estrictu sensu, y por tanto, responsabilidad de la entidad aseguradora, así haya aflorado un daño previo y sin aquél, como se sabe, no se abrirá paso la prestación dineraria a cargo del asegurador. (C. de Co., art. 1054), motivo por el cual, bien comprendido, entre ambos hitos existirá una estrecha relación, una especie de matrimonio, sin que ello implique una fusión o fundición. Elocuente es el contenido del artículo 1054 del Código de Comercio, que reza que riesgo es el "suceso incierto que no depende de la voluntad del tomador, del asegurado o del beneficiario, y cuya realización da origen a la obligación del asegurador", noción general que, en tratándose del seguro de la responsabilidad civil, se enriquece y complementa, en lo pertinente, con lo que explicita el artículo 1133 del estatuto comercial, el que impera que "En el seguro de responsabilidad se entenderá ocurrido el siniestro en el momento en que acaezca el hecho externo imputable al asegurado..."

Por tanto, el hecho activador de dicha reclamación, en puridad, no será únicamente el surgimiento del débito de responsabilidad en sí mismo considerado, sino también la reclamación judicial o extrajudicial que, en línea de principio, a diferencia del sistema convencional o tradicional, deberá formularse dentro de la vigencia del seguro, so pena de que no se obligue la responsabilidad de la entidad aseguradora o, en su defecto, en un término aledaño (post-contractum) de uno o dos años, como se acostumbra en la praxis, aun cuando hay otras que lo elevan a cinco, como incluso algunas legislaciones modernas lo reclaman, específicamente aquellas que del tema expresamente se ocupan (Francia, por vía de ilustración)” JARAMILLO. Derecho de Seguros. t. II. Op. Cit. p. 323 - 324. 
La tesis anterior, aunque mayoritaria, no es unánime situación que ha sido reconocida en laudo arbitral en el cual los árbitros al abordar el tema indicaron que la doctrina patria se encuentra dividida y, sin entrar en debates teóricos decidieron en todo caso indicar que la cobertura pendía de la reclamación y que es a partir de ese momento que debe iniciarse el cómputo del término de prescripción. En palabras del Tribual:

"Debe puntualizarse que en la doctrina se discute si en el sistema de reclamación hay o no un cambio de la noción de siniestro. Algunos opinan que el siniestro sigue siendo el hecho dañoso [Ordóñez], mientras otros entienden que el siniestro bajo esa modalidad es la reclamación [Jaramillo]. A nivel jurisprudencial, la Corte Suprema de Justicia, Sala de Casación Civil, se inclina por aceptar que en la modalidad claims made el siniestro es la reclamación [Fallo del 18 de diciembre de 2013 M.P. Fernando Giraldo Gutiérrez]. Al margen de la discusión enunciada lo cierto es que la reclamación es el elemento que activa la cobertura y determina los cómputos respectivos. Ahora bien, la Ley 389 de 1997 no define lo que debe entenderse por reclamación. Solo exige que sea una reclamación de la víctima en contra del asegurado o del asegurador. Por esta razón es usual que las pólizas incorporen definiciones de reclamación, las cuales han sido aplicadas sin que su validez haya sido discutida" ${ }^{29}$

Algunos autores patrios, ${ }^{30}$ afirman que, con la expedición de la Ley 389 de 1.997 y la incorporación de los seguros de responsabilidad civil por reclamación, no se modificó la definición o el concepto del siniestro en el seguro de responsabilidad civil.

29 Laudo Arbitral Proyectar Valores S.A. Comisionista de Bolsa en Liquidación forzosa administrativa contra Cubb de Colombia Compañía de Seguros S.A. y Chartis Seguros Colombia S.A. (2977) Centro de Arbitraje y Conciliación de la Cámara de Comercio de Bogotá. Árbitros: Carmenza Mejía Martínez; Juan Carlos Esguerra Portocarrero y Juan Manuel Díaz-Granados Ortíz.p. 51 -52.

30 Son de esa opinión los profesores Andrés Ordóñez Ordóñez y Bernardo Botero Morales. Por su parte, el doctor Carlos Darío Barrera sostiene una tesis particular, según la cual, para los seguros de responsabilidad civil bajo la modalidad claims made, la Ley 389 de 1997 incorporó una causal de caducidad, de manera que, de no presentarse la reclamación en vigencia de la póliza, caducará cualquier acción en contra de la aseguradora. En sus palabras: "En este punto y hora es menester dilucidar si la circunstancia de pactar un término dentro del cual se reciben reclamaciones implica que, si éstas no se efectúan en ese plazo, la obligación del asegurador prescribe o si es que, por el contrario, la acción ha caducado. Nosotros descartamos la prescripción y, por el contrario, pensamos que la figura encuadra dentro de la caducidad, en razón de que entender lo primero significaría que la Ley 389 de 1997 otorgó a las partes la posibilidad de pactar reducciones de los plazos de prescripción - no inferiores a 2 años - en absoluta contravía con el claro texto del artículo 1081 y con la doctrina y legislaciones modernas que rechazan los pactos acerco de los términos de prescripción. En cambio, la caducidad parece más acorde con la naturaleza misma de la figura, de tal manera que hay que entender que la reclamación dentro del término es un hecho que debe realizar el asegurado o beneficiario para poder acceder a la acción correspondiente." BARRERA TAPIAS, Carlos Darío. La prescripción de las acciones derivadas del seguro de responsabilidad civil. (Ley 389/97). En: Memorias del XXI Encuentro Nacional - Nuevas orientaciones del contrato de seguro en Colombia y en América Latina. Acoldese - Editorial Guadalupe. 1998. p. 147. 
El profesor Andrés Ordóñez, sostiene que: "La nueva ley, a mi juicio, no ha pretendido modificar el concepto de siniestro tal como se define, como ya se vio, en el artículo 1.131 del Código de Comercio: el hecho externo imputable al asegurado. Por lo mismo, al iniciar esta exposición se ha sostenido que la nueva ley lo que consagra a este respecto es la posibilidad de aseguramiento del riesgo putativo en el seguro de responsabilidad civil, en la medida que esa ley permite cubrir la incertidumbre acerca de la existencia de un siniestro en el paso, si ello es así, es porque el siniestro sigue siendo el hecho externo que ha causado el daño y que, conforme a la nueva ley, puede cubrirse siempre y cuando el asegurado desconozca que ese hecho ha ocurrido o, por lo menos, sus consecuencias dañosas". ${ }^{31}$

En la misma línea el profesor Bernardo Botero expresa:

"En síntesis, el hecho de que el asegurador, haciendo uso de la facultad que le confiere el artículo $4^{\circ}$ primer inciso de la Ley 389 de 1997, someta la obligación de indemnizar un evento objeto de cobertura a la prestación de reclamación por parte del damnificado bien al asegurado o bien al asegurador, dentro de un término especifico que consulte los requisitos de la citada norma, constituye, en nuestro criterio, una condición o requisito de exigibilidad de la obligación a cargo del asegurador, más no la redefinición del siniestro mismo.

Finalmente, no compartimos el argumento de que el hecho activador de la responsabilidad del asegurador es la reclamación formulada por el damnificado o por sus causahabientes. El hecho activador de la responsabilidad del asegurador, o sea, la razón de ser la obligación de indemnizar no puede, a nuestro juicio, ser otro que el daño causado por el asegurado e imputable a la responsabilidad de este. El que la reclamación de la víctima al asegurado deba realizarse dentro de un determinado lapso no es otra cosa, repetimos, que un requisito o condición adicional para hacer efectivo el pago de la indemnización." 32

A modo de resumen, los principales argumentos que se han esgrimido por los profesores Ordóñez y Botero para sustentar y defender su tesis, que contradice la idea de la modificación del concepto del siniestro en los seguros de "claims made", han sido los siguientes: 1) El siniestro sigue siendo el acaecimiento del hecho externo dañoso, sin

31 ORDÓÑEZ. Op. Cit. p. 126- 127

32 BOTERO MORALES, Bernardo. "Prescripción del derecho a la indemnización en el seguro por reclamación o claims made". En Derecho de Seguros y Reaseguros, Líber Amicorum en homenaje al profesor Arturo Díaz Bravo. Pontificia Universidad Javeriana - Grupo Editorial Ibáñez, 2015. P. 380 y 381 
él no habría ningún tipo de cobertura. La reclamación es simplemente una condición adicional de cobertura que no puede confundirse con el siniestro mismo; 2) Cuando se amparan hechos dañosos pretéritos simplemente se está dando cobertura a riesgos putativos, tal y como se podía hacer desde hace muchos años en materia de seguro marítimo y; 3) Si el siniestro fuera exclusivamente la reclamación, no sería necesario dar aviso al asegurador del simple acaecimiento de hechos y circunstancias dañosas, porque las mismas no serían un siniestro que debiera ser informado al asegurador en los términos del artículo 1075 del Código de Comercio.

Sin perjuicio de los buenos argumentos esgrimidos por los profesores Botero y Ordóñez para sostener una posición en contrario, se considera que tiene mayor solidez y consistencia la tesis mayoritaria, porque no resulta adecuado equiparar la reclamación constitutiva del siniestro con un simple condicionante adicional para que haya cobertura. De ser aceptada dicha concepción o teoría de un hecho compuesto para configuración del siniestro, las modalidades "claims made" y ocurrencia "sunset" serían virtualmente idénticas, siendo únicamente posible diferenciarlas en aquellos eventos en los que se otorgare cobertura retroactiva en los seguros por reclamación para brindar amparo igualmente a hechos ocurridos con anterioridad al inicio de la vigencia de la póliza.

De otra parte, no se comparte la afirmación de que los seguros de responsabilidad bajo la modalidad "claims made" son simplemente un mecanismo para dar cobertura a riesgos putativos dado que en criterio de este autor, ni el otorgamiento de coberturas retroactivas es esencial en los seguros por reclamación, ni tampoco nada impediría que se pactare expresamente por la partes contratantes, que se otorga cobertura a reclamaciones presentadas por primera vez en vigencia de la póliza, así las mismas, tengan su origen en hechos y circunstancias ya conocidas por el tomador y/o asegurado, incluso cuando de estas, se pudiere esperar razonablemente a futuro una reclamación.

Se reitera, que conforme la redacción del artículo 4 de la Ley 389 de 1994 y, la definición de riesgo asegurable prevista en el artículo 1054 del Código de Comercio, nada impediría que una compañía de seguros diera cobertura expresa a hechos y circunstancias conocidas por el asegurado, debidamente identificadas por las partes, siempre y cuando, no se hubiera verificado previo al inicio de la póliza una efectiva reclamación en contra del asegurado con base en dichos hechos y circuns- 
tancias. En otras palabras, lo único que no estaría permitido en materia de seguros de responsabilidad bajo la modalidad "claims made" sería asegurar siniestros ya ocurridos, por ausencia del elemento esencial denominado riesgo asegurable, situación que se presentaría únicamente en aquellos eventos en que hubiere mediado previo al inicio del seguro una reclamación en contra del asegurado.

Por último, en relación con el argumento referente a que resultaría ilógica la obligación de dar aviso o notificación a la aseguradora de hechos y circunstancias conocidos, cuando aún no se ha producido un siniestro, dado que el mismo consiste en la reclamación en sí misma y no en el acaecimiento del hecho dañoso, debe únicamente señalarse que dicha carga o deber en cabeza del asegurado, tiene su razón de ser en la naturaleza misma de los seguros por reclamación o "claims made", como será explicado más adelante y, que su aplicación, lo único que busca es generar una excepción a la regla general de configuración del siniestro para evitar con ello, absurdos vacíos de cobertura y notorias inequidades contractuales generadas por la inexorable delimitación temporal que con efectos a futuro encarna esta modalidad aseguradora.

Determinar si en los seguros de responsabilidad bajo la modalidad por reclamación o "claims made" se modifica o no la configuración del siniestro, no es de poca monta, razón por la que no debe considerarse este planteamiento como un debate meramente teórico, dado que el siniestro, es el momento crucial de la relación aseguradora, que origina, la que sin lugar a dudas es la principal obligación que surge de un contrato de seguro, así como su causa y razón de ser, el pago de prestación indemnizatoria a cargo de la compañía de seguro.

De la selección de una u otra tesis se desprenderán una serie de efectos jurídicos, tales como: el momento a partir del cual debe darse inicio del cómputo de la prescripción, la marcación o selección de la póliza que debería ser afectada en caso de que un mismo asegurado cuente con varios contratos de seguro para amparar su responsabilidad, sin que ello necesariamente implique coexistencia de seguros y, por supuesto, el detonante para dar lugar a una serie de obligaciones a cargo del asegurado/beneficiario que sólo tienen cabida con posterioridad a la verificación del siniestro mismo.

Con fundamento en los argumentos enunciados atrás se considera que la solución más sólida jurídicamente hablando, es la sostenida 
por la corriente mayoritaria, razón por la que se comparte sin salvedad alguna, que en los seguros de responsabilidad bajo la modalidad por reclamación o claims made se modificó la configuración del siniestro, siendo ahora este, la reclamación misma y no el acaecimiento del hecho dañoso, con todas las consecuencias, implicaciones jurídicas que de dicho señalamiento se desprenden.

\subsection{Modalidades existentes de "claims made", con coberturas retroactivas y ultractivas o prospectivas}

Existen variadas clasificaciones y diferentes modalidades o variaciones de cláusulas "claims made", pues en ellas siempre se encuentra presente la creatividad de los suscriptores de seguros y reaseguros y, en algunos puntuales casos, la capacidad de discusión y negociación por parte de los tomadores y asegurados.

El profesor Fernando Sánchez Calero manifiesta que la cobertura otorgada por las pólizas bajo la modalidad por reclamación o "claims made" consiste en amparar aquellos perjuicios que sufra el asegurado con ocasión de reclamaciones de responsabilidad civil que le sean formuladas durante la vigencia de la póliza, por hechos dañosos que hayan acaecido durante ese periodo. Sin embargo, aclara que la cobertura otorgada no se queda únicamente en ello, sino que es usual que se extienda en un doble sentido, a saber:

“(...) la delimitación temporal de la cobertura se produce, por regla general, respecto a las reclamaciones presentadas al asegurado en el periodo de vigencia del contrato (periodo de vigencia que se fija en las condiciones particulares) por los hechos dañosos cometidos durante dicho periodo. No obstante la cobertura del asegurador se extiende normalmente en un doble sentido: en primer término, el referido llamado periodo de retroactivo, en cuanto el asegurador es responsable del pago del siniestro también en el caso de aquellas reclamaciones al asegurado que se efectúen en el periodo de vigencia del contrato respecto a hechos dañosos que sean anteriores al mismo, pero cuya existencia fuera desconocida por él; en segundo término, en el periodo de extensión de la cobertura (denominada por algunas condiciones especiales como "periodo informativo", "periodo adicional de notificación", "periodo de descubrimiento") en cuanto prevén tales condiciones especiales que extinguido el contrato de seguro por cualquier causa (salvo por impago de prima) su cobertura puede extenderse si, en el término de treinta días siguientes a la fecha de la extinción del contrato, el tomador del seguro solicita del asegurador que prosiga la cobertura de las reclamaciones formuladas al asegurado, por hechos dañosos acaecidos durante un periodo de 
seguro, durante un tiempo que las pólizas fijan normalmente en doce meses (y que en algún caso pueden extenderse hasta los dos años)..." ${ }^{33}$

Con propósitos académicos algunos autores plantean diversas clasificaciones, por ejemplo, Juan Manuel Díaz-Granados ${ }^{34}$ diferencia entre las cláusulas "claims made" puras, "claims made" con retroactividad, "claims made" con necesidad de reporte durante la vigencia, "claims made" con cobertura futura para hechos y circunstancias conocidas y reportadas y, "claims made" con periodo extendido de reporte. Por su parte, Carlos Ignacio Jaramillo ${ }^{35}$ las divide en cláusulas "claims made" puras, "claims made" con cobertura retroactiva y "claims made" con cobertura prospectiva.

Por considerarla genérica e ilustrativa, se utilizará en este escrito la clasificación descrita por el profesor Jaramillo para hacer referencia a las principales modalidades de cláusulas "claims made" que pueden encontrarse en el mercado de seguros y reaseguros colombiano.

\subsection{1 "Claims made" puras (sin periodo de retroactividad)}

Buena parte de la doctrina ${ }^{36}$ considera que el sistema "claims made" puro es aquel por virtud del cual se amparan las circunstancias de responsabilidad civil reclamadas y ocurridas durante la vigencia de la póliza. En palabras de Juan Manuel Díaz-Granados, la modalidad pura es aquella que: “(...) cubre las reclamaciones presentadas durante la vigencia del seguro, siempre y cuando los hechos hubiesen ocurrido durante la vigencia de la respectiva póliza. Es decir, tanto el hecho generador, como la reclamación deben tener lugar estando vigente el periodo de protección de la póliza". ${ }^{37}$

En contra de la anterior posición el jurista Francisco Miranda Suárez sostiene que en las cláusulas "claims made” puras: “(...) la recla-

33 SÁNCHEZ CALERO. El seguro de responsabilidad civil para administradores, directores, y gerentes de las sociedades mercantiles. Op. Cit. p. 114.

34 DÍAZ-GRANADOS. Op. Cit. p. 161 - 164

35 JARAMILLO. Derecho de Seguros. t II. Op. Cit. p. 438 y ss.

36 Son de esta opinión: DÍAZ-GRANADOS Op. Cit. p. 161, SÁNCHEZ CALERO. El seguro de responsabilidad civil para administradores... Op. Cit. p. 28 y; FERNÁNDEZ DEL MORAL DOMÍNGUEZ, José. El seguro de responsabilidad civil de administradores y altos directivos de la sociedad anónima (Póliza D\&O) Granada. Editorial COMARES. 1998. p. 224 
mación debe producirse durante el periodo de vigencia de la póliza, con independencia de cuando haya ocurrido el hecho que lo genera". ${ }^{38}$ El profesor Bernardo Botero ${ }^{39}$ comparte el criterio anterior y considera también que son cláusulas "claims made" puras aquellas en las que, para que se verifique amparo o cobertura por el seguro, basta únicamente la presentación de una reclamación durante el periodo de vigencia de la póliza, sin que importe la fecha en la que haya acaecido el hecho dañoso que dio pie a la responsabilidad civil del asegurado.

$Y$ es verdad que no tiene mucho sentido ni asidero que se denomine "puro" un sistema más restrictivo, en el cual además de la reclamación, debe también cumplirse con el requisito de ocurrencia del hecho dañoso durante la vigencia de la póliza. El vocablo puro ${ }^{40}$ implica de suyo exclusividad y ausencia de combinación o mezcla con otras modalidades, de manera que, así como es ocurrencia pura, el sistema en el cual se ampara la responsabilidad civil del asegurado por hechos dañosos ocurridos durante la vida o vigencia del seguro, sin que sea relevante para ello la fecha en que se manifiesten dichos daños o se reclame su responsabilidad. En igual sentido debería ser puro el sistema de "claims made" en el que el único condicionante para detonar la prestación indemnizatoria a cargo del asegurador sea la presentación de una reclamación por parte de la víctima.

En estricto sentido, las cláusulas "claims made" puras deberían ser aquellas en las cuales se otorgue amparo a las reclamaciones que se eleven en contra del asegurado durante la vigencia de la póliza sin importar la fecha en que hubiese ocurrido el daño reclamado por la víctima o en que se hubiera verificado la comisión del hecho dañoso que pudiera dar lugar a la responsabilidad del asegurado. En otras palabras, debería entenderse como "claims made" puro aquél esquema, en el cual se otorga retroactividad ilimitada y donde lo único que determina la validez de un siniestro es la reclamación misma, sin que importe o tenga relevancia alguna la fecha en que ocurriera el hecho dañoso que dio pie a la imputación de responsabilidad civil al asegurado.

Dejando atrás el debate sobre el acierto del nombre asignado a este tipo de cláusulas "claims made", es pertinente mencionar que existen

38 MIRANDA SUÁREZ. Op. Cit. p. 112.

39 BOTERO. La teoría y la práctica del seguro por reclamación o seguro claims made. Op. Cit. p. 4 - 5.

40 Según el diccionario de la Real Academia Española de la Lengua: "Puro(ra) 1. adj. Libre y exento de toda mezcla de otra cosa; (...) 3. adj. Que no incluye ninguna condición, excepción o restricción ni plazo.; (...) 6. adj. Mero, solo, no acompañado de otra cosa. (...)" 
algunas cláusulas, en las que no sólo se exige que la ocurrencia del hecho dañoso y la reclamación por parte del tercero se produzcan durante la vigencia del seguro, sino que, adicionalmente se establece que deberá darse aviso o reporte formal de dicha circunstancia por parte del asegurado a la compañía de seguros antes de la expiración de la póliza como condición indispensable para el otorgamiento de cobertura. ${ }^{41}$

Tal sistema ${ }^{42}$, aún más restrictivo que el anterior, es conocido normalmente en el mercado de seguros y reaseguros como " "claims made and reported", que en castellano implicaría reclamación hecha y reportada. Es bueno acotar que la exigencia del reporte al asegurador no es exclusiva de la denominada modalidad "pura", dado que puede hacer parte de cualquier esquema o modalidad de cláusulas "claims made", incluso si en ellas se contemplaren coberturas retroactivas y prospectivas. La modalidad "claims made and reported" simplemente es una variación en la que, para efectos de otorgamiento de cobertura y afectación de una póliza de seguro de responsabilidad, se exige, que en adición a la reclamación en vigencia de la póliza se dé, por parte del asegurado, reporte escrito de dicha circunstancia a la compañía de seguros.

Específicamente, en lo que respecta a la puntual modalidad denominada como "claims made and reported" se considera, como será revisado en detalle más adelante, que existen serias razones que permitirían cuestionar su eficacia jurídica, dada su manifiesta contradicción a algunas normas imperativas previstas en el ordenamiento jurídico colombiano. Lo que, en la práctica implicaría la absoluta imposibilidad jurídica para que los particulares la incluyeran, válidamente, en ejercicio de su autonomía privada, en sus contratos de seguro de responsabilidad, tal y como fue tácitamente reconocido en sentencia del 31 de julio de 2014 proferida por la Corte Suprema de Justicia, en su Sala de Casación Civil, fallo en el cual se indicó que la consecuencia de no reportar o notificar la presentación de una reclamación a la aseguradora no sería la pérdida del derecho a ser indemnizado, sino únicamente la eventual reducción de los perjuicios que sufriere por

41 DÍAZ-GRANADOS. Op. Cit. p. 163.

42 En el mercado internacional usualmente este esquema se utiliza en el clausulado de Lloyd's- LSW735 que valga la pena mencionar más que un simple aviso de la circunstancia al reasegurador exige prácticamente la reclamación misma del siniestro a este. 
dicha infracción la compañía de seguros en los términos del artículo 1078 del Código de Comercio. ${ }^{43}$

Retomando el tema inicialmente planteando y con relación a la denominada modalidad "claims made" pura que exige que tanto la reclamación como el hecho generador de la responsabilidad se verifiquen o tengan lugar durante la vigencia de la póliza (con mayor razón y sin lugar a controversia en aquella en el que se exige ocurrencia, reclamo y reporte), la doctrina con muchas voces ha tendido a considerar que se trata de una modalidad excesivamente restrictiva, que podría calificarse mínimamente como abusiva al generar un desequilibrio injustificado en contra del asegurado. Son de esa opinión Carlos Ignacio Jaramillo ${ }^{44}$ y Francisco Suárez, ${ }^{45}$ entre otros.

Aunque en principio se entiende y comparte la preocupación doctrinal y sus cuestionamientos referentes al posible abuso o desequilibrio contractual que se produce con la estipulación de la denominada modalidad "claims made" pura, por su notable carácter restrictivo en contra de los intereses del asegurado, deben tomarse en consideración dos aspectos fundamentales que podrían llevar a pensar que las denominadas modalidades "claims made" puras, no sólo serían admisibles bajo el ordenamiento jurídico colombiano, sino que adicionalmente, no necesariamente implicarían un desequilibrio contractual o lesión de los intereses del asegurado.

El primer aspecto, es que la ley colombiana, concretamente el artículo 4 de la Ley 389 de 1997, fue redactada en forma notablemente

43 CORTE SUPREMA DE JUSTICIA. Sala de Casación Civil. Sentencia del 31 de julio de 2014. MP Ruth Marina Díaz. Rad. N 110001-3103-015-2008-00102-01. "Ahora, a pesar de que dicho «reclamo»lo recibió la «asegurada» el «14 de septiembre de 2006», y no lo informó a la «aseguradora» de manera inmediata conforme lo exigido en el convenio en mención, sino hasta el «11 de diciembre de 2006», el mismo no queda excluido del amparo, toda vez que fue allegado a la C......... D.. C........... D. B........... «durante la vigencia de la póliza», la que valga recordar, abarcó desde el «30/11/2005 hasta el 30/11/2006», y según lo estipulado, es la "presentación del reclamo», el que se toma en cuenta para la configuración del «siniestro», supuesto este que se adecúa a la segunda hipótesis determinada en el precedente jurisprudencial antes reproducido para que opere la cobertura, toda vez que el hecho perjudicial aconteció el «2 de agosto de 2004» al efectuarse el «registro del acta de aprobación de la liquidación de la sociedad L... D.. B.......... S.A.», en tanto que el «reclamo a la asegurada» se realizó hallándose en vigor el "contrato de seguro»

Cabe acotar, que a pesar de haberse realizado la notificación del «siniestro» a la "aseguradora», no con la celeridad pactada, esa situación no genera la pérdida del derecho, sino que podría producir las consecuencias señaladas en el artículo 1078 del Código de Comercio, el que faculta al «asegurador» para "deducir de la indemnización el valor de los perjuicios que le cause dicho incumplimiento»." (Se subraya por fuera del texto original).

44 JARAMILLO. Op.Cit. 340.

45 MIRANDA SUÁREZ. Op. Cit. p. 118. 
amplia, lo que permitiría la utilización en Colombia de prácticamente cualquier tipo o modalidad de cláusula "claims made", incluyendo, por supuesto, aquellas en las cuales se determine que el hecho detonante de la cobertura deba ocurrir y ser reclamado por la víctima al asegurado o a su aseguradora durante el periodo de vigencia de la póliza. Esta amplitud y libertad de estipulaciones concedida a los particulares en materia de seguros de responsabilidad, implica que difícilmente se pueda hablar de ilegalidad para este tipo de cláusulas, contrario a lo que sí acontecería en las legislaciones francesas y españolas cuyos textos normativos son más restrictivos y exigen unos mínimos de coberturas retroactivas que no fueron contempladas en Colombia. ${ }^{46}$

En segunda medida, debe reconocerse que existen varios eventos en los cuales la mal llamada modalidad "claims made" pura (reclamación más ocurrencia durante la vigencia de la póliza) es innegablemente útil para el asegurado sin que se le genere ningún perjuicio o desequilibrio contractual. Por ejemplo, cuando se contrata un seguro de responsabilidad civil por primera vez, bien fuere porque en el pasado no tuviera contratada ningún tipo de cobertura de responsabilidad civil o porque se tratase del inicio de nuevas actividades económicas, no es indispensable que se confiera al asegurado una cobertura por hechos pretéritos, es decir periodo de retroactividad. Es elemental que, si nada había en el pasado, no podría alegarse la lesión del asegurado por no amparar con efectos retroactivos.

Lo que sí resulta indispensable en aras de evitar vacíos de cobertura y desequilibrios contractuales, es que cuando se renueve anualmente la póliza de responsabilidad por reclamación se pacte que se otorgará, lo que normalmente es conocido en el sector asegurador como "retroactividad al inicio" o "retroactividad al inicio de la primera póliza", que permite que las nuevas pólizas expedidas cubran reclamaciones que sean presentadas al asegurado y que tengan origen en hechos que tuvieron lugar con posterioridad al primer día que contrató el primer seguro. En otras palabras, se trataría de una especie de cobertura retroactiva ligada íntimamente a la renovación ininterrumpida del seguro contratado, la cual, en caso de faltar generaría notables vacíos de cobertura.

Como será analizado más adelante en este escrito, más importante aún que el otorgamiento de coberturas retroactivas, lo fundamental en

46 Al respecto se puede consultar el trabajo de Juan Manuel Díaz-Granados, en el que se describen detalladamente la regulación de las cláusulas claims made en el extranjero. Op. Cit. p. 164 y ss. 
materia de seguros de responsabilidad civil bajo la modalidad "claims made" es el otorgamiento de los denominado periodos prospectivos de amparo, puesto que la verdadera restricción o delimitación temporal que persiguen los seguros de este tipo, no es hacia el pasado, sino, precisamente, hacia el futuro.

Conforme lo hasta aquí expresado, es imperativo apartarse de las voces de protesta expuestas, y concluir que la denominada modalidad "claims made" pura (se deja salvedad que aquí no se hace referencia a la modalidad "claims made and reported" cuyo análisis se retomará para reafirmar su notable ilegalidad e inconveniencia) no sólo es legítima a la luz del ordenamiento jurídico colombiano, sino que, en la práctica, tan sólo en muy puntuales ocasiones pudiera generar desequilibrio económico o lesión de los intereses del asegurado.

\subsection{2 "Claims made" con retroactividad}

Bajo esta modalidad de "claims made" se da cobertura a aquellas reclamaciones que se presenten en vigencia de la póliza y que tengan su origen en hechos y circunstancias acaecidas durante la vigencia de la misma o incluso con anterioridad al inicio de su vigencia, siempre y cuando dichos hechos se hubieren producido con posterioridad a la fecha máxima de retroactividad establecida por el asegurador en las condiciones particulares del seguro. En otras palabras, se permite adicionalmente brindar amparo a reclamaciones generadas por hechos ocurridos con anterioridad, al inicio de la vigencia de la póliza, siempre y cuando los mismos se encuentren dentro del rango de tiempo pretérito otorgado.

Por virtud de las modalidades retroactivas se incorpora al seguro de responsabilidad, en buena parte, una forma de aseguramiento del denominado riesgo putativo ${ }^{47}$, pues se terminan cubriendo, por regla general, hechos pretéritos o pasados, bajo la condición genérica, de que los mismos sean efectivamente desconocidos por un asegurado diligen$\mathrm{te}^{48}$. Sobre el particular, afirma Díaz-Granados: "Es preciso tener en

47 Lo anterior sin perjuicio de lo que ya fue aclarado líneas atrás en torno a que la posibilidad de dar amparo a riesgos putativos, no es óbice para considerar que en materia de seguros de responsabilidad el siniestro consista en la reclamación misma y ya no en la ocurrencia del hecho daños en vigencia de la póliza.

$48 \mathrm{Al}$ hacer referencia a un asegurado diligente nos referimos a que no haya tenido tampoco la posibilidad de haber conocido dichos hechos, lo que implica una buena objetiva y ausente de cualquier tipo de culpa. 
cuenta que estos hechos deben ser desconocidos para el asegurado, pues, de lo contrario, la generalidad de las pólizas contempla una exclusión denominada hechos o circunstancias anteriores. Esta exclusión se refiere a cualquier hecho o circunstancia que era conocida o que razonablemente debió haber sido conocida por el asegurado, la cual podia, razonablemente, dar lugar a un reclamo. Este concepto presenta en ocasiones un alto grado de complejidad en su aplicación". ${ }^{49}$

Siguiendo la línea argumentativa que sostiene que sólo podrían calificarse como "claims made" puras aquellas que ofrezcan retroactividad ilimitada, sería adecuado concluir que la primera restricción que se pudiera incluir a las cláusulas "claims made", sería precisamente limitar la retroactividad ofrecida. De tal suerte, entre mayor sea el número de años concedidos, menor sería la delimitación impuesta.

Valga mencionar que, en ocasiones, el otorgamiento de un periodo de retroactividad resulta innecesario para los intereses del asegurado o de las potenciales víctimas. Piénsese, por ejemplo, en el caso de una empresa que recién comienza su actividad económica, o en el caso, ya comentado, de una persona que cambia su esquema de cobertura de ocurrencia pura a "claims made". En esos eventos, en que haciendo tránsito de un esquema de cobertura por ocurrencia pura a uno de "claims made" con retroactividad, lo único que se haría sería consolidar una coexistencia de seguros que sólo podría ser útil para un asegurado, si la suma o valor asegurado que tenía en sus pólizas pasadas era insuficiente para sus niveles de exposición.

Contrario sensu, una cobertura por reclamación con periodo de retroactividad sí podría resultar muy útil, al menos en teoría, para subsanar vacíos de cobertura, como aquellos que pudiera dejar el sistema de ocurrencia con delimitación temporal o sistema de ocurrencia con cláusula "sunset".

\subsection{3. "Claims made" con coberturas prospectivas}

En adición a la cobertura por reclamación "pura" y al otorgamiento de un periodo de retroactividad, las cláusulas "claims made" permiten el uso de otras herramientas, que con regularidad están presentes en los contratos de seguro de responsabilidad que se comercializan en el

49 DÍAZ-GRANADOS. Op. Cit. Pág. 162. 
mercado $^{50}$ y que otorgan a los seguros contratados la posibilidad de extender a futuro su amparo en aras de evitar vacíos de cobertura y desequilibrio económico del contrato de seguro de responsabilidad civil bajo esta modalidad.

En referencia a estos tipos de cláusulas "claims made" con efectos prospectivos o posteriores a la terminación del contrato de seguro, indica el profesor Jaramillo que: "Esta tipología, igualmente conocida como estipulación "claims made con cobertura ulterior", o "cláusula de cobertura posterior", o "subsiguiente o post contractum”, entre otras denominaciones más, hunde sus raíces en la finalidad de ampliar el espectro temporal de la cobertura, en principio limitado al término de vigencia del seguro, a fin de que se extienda un tiempo más, concretamente el periodo que ex voluntate se pacte, el que por ello se conoce ordinariamente como "periodo post-contractum", pues funge como un lapso aledaño, adicionado o agregado". ${ }^{51}$

Cuando se habla de coberturas de tipo prospectivas se hace referencia, principalmente, a los denominados "periodos extendidos de reporte", también llamados "término adicional para notificaciones", y a la cláusula de notificación al asegurador de hechos y circunstancias conocidas durante la vigencia de la póliza que pudieran dar lugar a una futura reclamación.

Con relación a estas modalidades prospectivas, valga aclarar que, más que nuevas formas o tipos de cláusulas las "claims made" son herramientas o instrumentos requeridos por el sistema de delimitación temporal por reclamación para poder operar en debida forma y evitar notables y perjudiciales vacíos de cobertura a futuro.

\subsubsection{Periodo Extendido de Reporte o Adicional para Notificaciones}

Es una prerrogativa, consignada normalmente en una cláusula del condicionado general del seguro que confiere al tomador/ asegurado, ${ }^{52}$ la

50 Por lo menos en los seguros de D\&O, infortunadamente no siempre en los seguros de responsabilidad de servidores públicos y en los seguros de RC médica, razón por la que debe tenerse cuidado al adquirir dichas pólizas, para comprobar si se están otorgando dichas modalidades de cobertura prospectivas.

51 JARAMILLO. Derecho de Seguros. Tomo II. Op. Cit. p. 342 - 343.

52 Es importante mencionar que, en materia de seguros de responsabilidad civil colectivos, como lo sería un seguro de RC médica o concretamente el seguro de D\&O, la potestad para optar por el periodo extendido de reporte se conceda a favor del tomador del seguro y no específicamente a favor de los asegurados. 
posibilidad de obtener cobertura de parte de la compañía de seguros para aquellos reclamos que reciba con posterioridad a la terminación o no renovación de la póliza. Reclamos que deberán fundarse, únicamente, en hechos ocurridos con anterioridad a la expiración de la póliza, bien sea dentro de su vigencia o dentro del periodo de retroactividad otorgado por el asegurador.

El denominado periodo extendido de reportes es normalmente consignado en los diferentes textos de seguros de responsabilidad civil bajo la modalidad por reclamación como un amparo adicional otorgado por la aseguradora a favor del asegurado. De hecho, normalmente cada compañía de seguros utiliza un nombre o título diferentes para referirse a esta prerrogativa. A manera de ejemplo en los clausulados de seguros de responsabilidad de Directores y Administradores D\&O, se consigna el periodo extendido de reporte así: AIG Seguros y Ace Seguros la denominan como Periodo de descubrimiento, Chubb Seguros y Allianz Colseguros como Periodo Adicional de Notificación y Suramericana de Seguros como Cobertura para Periodo Adicional para Notificaciones. ${ }^{53}$

De los textos anteriormente mencionados se pueden destacar las siguientes características o condiciones que usualmente contienen los denominados periodos extendidos de reporte:

- Dicha cobertura sólo tiene cabida en los eventos en que finalice el amparo que venía siendo otorgado, ya fuere por revocación unilateral de alguna de las partes o por mutuo acuerdo. En todo caso, únicamente habrá lugar al periodo extendido de reportes si no se contrata una nueva póliza que remplace la cobertura finalizada o extinta.

- Debe manifestarse, en principio, por parte de la entidad tomadora a la aseguradora la intención de contratarlo dentro de un término máximo fijado en las condiciones particulares, manifestación que adicionalmente deberá venir acompañada del correspondiente pago de la prima a que hubiere lugar. Normalmente, dicha manifestación por parte de la entidad tomadora o de los asegurados debe realizarse

53 ChUBB DE COlOMBIA COMPAÑÍA DE SEguros S.A. Chubb Direct\&vos. Póliza de responsabilidad civil para directores y administradores. Código 20/12/2012-1321-P-06-CHUBB DIRECT\&VOS-; ALLIANZ SEGUROS S.A. Póliza de Seguro de responsabilidad para miembros de junta directiva y demás administradores Allianz Pro. Registro: 21/04/2011-1301-P-06-D\&O V1; - AIG SEgUROS COLOMBIA S.A. Seguro de responsabilidad civil D\&O empresarial. Código 10122012-1322-P-06-D\&OEMPRESARIAL; ACE SEGUROS DE COLOMBIA S.A. Registro. 10/02/2011-1305-P-06-12RCD\&O003; - SEGUROS GENERALES SURAMERICANA S.A. Seguro deresponsabilidad civilparadirectoresyadministradores. Registro01/06/2009-1318-p-12-F-01-13-036. 
con posterioridad a la terminación de la póliza que venía contratada, sin embargo hay algunas compañías que exigen que dicha manifestación se realice de manera anticipada a la finalización de la misma, requisito que pudiera ser innecesario e incluso absurdo, dado que en la mayoría de los casos el periodo extendido de reporte tiene cabida cuando fenece la cobertura, lo que normalmente sucede de manera abrupta e intempestiva, como sería el caso de la revocación unilateral del seguro, de manera que anticipar dichas eventualidades resultaría prácticamente imposible para la entidad tomadora y el asegurado, haciendo nugatoria la prerrogativa objeto de estudio.

- No habrá lugar al periodo extendido de reporte si la póliza terminó automáticamente por mora en el pago de la prima, dado que, siendo un beneficio a favor del asegurado, sólo puede accederse a este si se ha dispensado debido cumplimiento a las obligaciones que para el tomador y asegurado se derivan del contrato de seguro.

- En el periodo extendido de reporte sólo se cubrirán reclamaciones que provengan de hechos ocurridos con anterioridad a la expiración de la póliza, no se ampararán bajo ninguna circunstancia hechos acaecidos durante el periodo extendido. Esta particularidad del periodo extendido de reporte tiene fundamental importancia para aquellos eventos en los que el seguro termina por alguna expresa disposición contractual ligada a una agravación del estado del riesgo. El periodo extendido de reporte no implica para la aseguradora la asunción de un riesgo diferente o más gravoso del que venía amparando hasta la fecha, sino únicamente la concesión de un plazo de gracia, de un amparo prospectivo que permita reclamaciones desconocidas motivadas en hechos ya ocurridos y que pudieran ser formuladas en un futuro próximo a los asegurados.

- Algunas pólizas consideran igualmente como reclamos reportados la notificación a la compañía de seguros del conocimiento de hechos y circunstancias constitutivos de un eventual siniestro o reclamo que, acaecidos antes de la expiración de la póliza fueren conocidos por primera vez durante el periodo extendido de reporte. Esta posibilidad implica una notable ventaja en términos de cobertura porque se ampararían futuras reclamaciones así las mismas no se materialicen durante el periodo de reporte mismo.

- El periodo extendido de reporte implica cobro de prima adicional dado que por regla general no es gratuito. Dicho importe será fijado 
desde el inicio en las condiciones particulares de la póliza de manera que su precio no sea ni sorpresivo, ni secreto para la entidad tomadora y/o asegurados.

- Verificada la reclamación durante el periodo extendido de reporte se entenderá como si la mencionada reclamación hubiera tenido lugar durante la última vigencia del seguro, de manera que serán aplicables todas las condiciones técnicas (amparos, exclusiones, límites, sublímites, deducibles, etc.) correspondientes a la última vigencia contratada, siendo por demás importante tener presente, que los límites asegurados arrastrarán a esta etapa cualquier uso o disminución que hubieren tenido antes de iniciar el periodo extendido.

- Sin perjuicio del reparo legal que pudiera surgir al respecto y que, para esta modalidad de cobertura prospectiva, estaría justificado, algunos clausulados consagran que para que opere la cobertura no bastará con la simple reclamación, sino que será necesario su reporte a la aseguradora antes de que finalice la extensión pactada.

- El término de la extensión variará dependiendo de cada clausulado y del monto de la prima que sea cobrado, lo usual es que periodo concedido oscile entre 12 y 36 meses.

- Debe criticarse que en algunos clausulados se consagra que el simple ofrecimiento de términos de renovación por parte de la aseguradora impedirá que se considere que ha habido revocación o falta de intención de renovar la cobertura por parte de esta, enervando de esa forma el derecho del asegurado/tomador de adquirir la protección extendida. Sin lugar a dudas no cualquier ofrecimiento de renovación puede considerarse como idóneo para enervar dicho derecho a favor del asegurado, únicamente una oferta sensata e equitativa irradiada en el principio de buena fe contractual podría cumplir dicho propósito, que por cierto deberá ser revisado caso por caso

- Por último, es pertinente mencionar que algunos clausulados del mercado consagran que la presente prerrogativa puede ser ejercida por parte de la entidad tomadora o de los asegurados, sin embargo, tratándose de estos últimos no se aclara si su manifestación de intención de adquisición del periodo extendido compromete la voluntad de todos o únicamente del asegurado que manifestó su consentimiento. Tampoco es claro si es posible que se otorgue el periodo extendido de reporte únicamente a un solo administrador asegurado, ni mucho menos qué porcentaje de la prima total deberá 
pagar por su extensión personal. Lo cual hace que si bien exista en teoría dicha posibilidad en la práctica sea muy complicado su ejercicio.

\subsubsection{Notificación de Hechos o Circunstancias que pudieran dar lugar a un reclamo}

Consiste en la prerrogativa que tiene el asegurado de notificar o informar a su asegurador sobre el acaecimiento de hechos o circunstancias, durante la vigencia de la póliza o del periodo de retroactividad otorgado, conocidos por primera vez por el asegurado durante la vigencia del seguro o durante el periodo extendido de reporte y que, en su criterio, pudieran razonablemente dar lugar a una futura reclamación. De tal manera, en caso de que efectivamente se recibiera dicha reclamación posteriormente, la misma se entendería hecha y, por ende, cubierta bajo la póliza de seguro vigente al momento en que se hizo la notificación de tales circunstancias al asegurador.

Para la doctrina esta condición de los seguros "claims made" permite que se extienda la cobertura de la póliza a: “(...) todos los hechos que sean conocidos por el asegurado durante la vigencia, los cuales pudieran razonablemente dar lugar a un reclamo, siempre y cuando sean notificados a la aseguradora durante la vigencia de la póliza o durante el periodo adicional para notificaciones, si este hubiese sido contratado. Si en el futuro tales hechos generan alguna reclamación, se considerará que tal reclamo ha sido presentado durante el correspondiente periodo de vigencia en el que dichos hechos fueron comunicados a la compañia de seguros por primera vez". ${ }^{54}$

La institución en mención conlleva a que los seguros por reclamación varíen de cierta manera su "modus operandi", pues con ella se otorga cobertura a hechos simplemente reportados al asegurador durante la vigencia del seguro, así los mismos no hayan sido aún reclamados por parte de la víctima, al asegurado o a la compañía de seguros. Como se revisará por extenso más adelante, este mecanismo, al igual que el denominado periodo extendido de reporte, debe considerarse como connatural al seguro de responsabilidad bajo la modalidad "claims made", pues su existencia permite la debida operatividad de esta forma de aseguramiento $\mathrm{y}$, de paso, previene eventuales fuentes de desequilibrios

54 DÍAZ-GRANADOS. Op. Cit. p. 163. 
contractuales para los contratantes provocados por comportamientos abusivos en los que pudieran incurrir durante la ejecución del contrato.

Por ejemplo, por parte del asegurado, quien al no tener aliciente alguno para notificar la ocurrencia de hechos relevantes conocidos podría decidir callarlos, postergando así para el momento del siniestro (reclamación) cualquier debate en torno a una eventual reticencia de su parte o a su efectivo conocimiento de dichas circunstancias. Y, muy especialmente, por parte del asegurador, dado que la ausencia de dicha cláusula podría dar lugar a una constante y notoria fuente de vacíos de cobertura por cuanto los hechos acaecidos y conocidos por el asegurado podrían no estar amparados ni por la póliza vigente al momento de su acaecimiento, al no haber mediado aún reclamación en contra del asegurado, ni tampoco por la póliza vigente al momento de la efectiva reclamación porque en estricto sentido se trataría de un hecho excluido del amparo de la póliza al haber sido previamente conocido por el asegurado.

\subsection{Las formas prospectivas de amparo son un elemento connatural a los seguros bajo la modalidad "claims made"}

Previo a continuar con el estudio del sistema de cobertura por reclamación, es fundamental reiterar que las dos prerrogativas o formas de cobertura prospectiva que fueron atrás explicadas, es decir, tanto la institución denominada como periodo extendido de reporte, como la denominada notificación de hechos y circunstancias conocidos que pudieran dar pie razonablemente a una futura reclamación, son elementos básicos para que pueda operar en debida forma un seguro de responsabilidad bajo la modalidad "claims made", razón por la que se estima deberían considerarse como elementos que se desprenden de su naturaleza misma.

El artículo 1.501 del Código Civil, ${ }^{55}$ norma expresamente invocada por la legislación comercial colombiana por el célebre artículo 822 del Código de Comercio, diferencia entre elementos esenciales, naturales

55 CÓDIGO CIVIL. "Artículo 1501. < Cosas esenciales, accidentales y de la naturaleza de los contratos>. Se distinguen en cada contrato las cosas que son de su esencia, las que son de su naturaleza, y las puramente accidentales. Son de la esencia de un contrato aquellas cosas sin las cuales, o no produce efecto alguno, o degeneran en otro contrato diferente; son de la naturaleza de un contrato las que, no siendo esenciales en él, se entienden pertenecerle, sin necesidad de una cláusula especial; y son accidentales a un contrato aquellas que ni esencial ni naturalmente le pertenecen, $y$ que se le agregan por medio de cláusulas especiales." 
y accidentales de un contrato o convención jurídica, indicando que son elementos de la naturaleza aquellos que no siendo esenciales se entienden pertenecerle al negocio jurídico sin que hubiere necesidad de una expresa consagración o inclusión mediante cláusula especial, y que por virtud del principio de buena fe contractual consignado en los artículos $1.603^{56}$ del Código Civil y $871^{57}$ del Código de Comercio, los contratos obligan no solamente a lo pactado expresamente en ellos, sino a todo aquello que se desprenda de su naturaleza según la ley, la costumbre y/o la equidad natural. ${ }^{58}$

Conforme lo anterior deben calificarse las modalidades de cobertura prospectiva en comento como elementos de la naturaleza de los contratos de seguros de responsabilidad civil bajo la modalidad "claims made" y, por ende, debe concluirse que las mismas se entienden necesariamente incorporadas en todos los contratos de seguro de este tipo, sin que para el efecto fuese indispensable que en el condicionado general de la póliza, o en la carátula de condiciones particulares, se hiciese mención expresa o consagración formal de estas. Por consiguiente, sería totalmente contrario al principio de la buena fe contractual el desconocimiento e inobservancia por cualquiera de las partes contratantes de las modalidades prospectivas de coberturas en los seguros de responsabilidad civil por reclamación, salvo, claro está, que para el efecto hubiere mediado pacto expreso en contrario.

Considerar como un elemento de la naturaleza del contrato de seguro de responsabilidad bajo la modalidad "claims made” la prerrogativa correspondiente a la notificación de hechos y circunstancias conocidas

56 CÓDIGO CIVIL. "Artículo 1603. < Ejecución de buena fe $>$. Los contratos deben ejecutarse de buena fe, y por consiguiente obligan no solo a lo que en ellos se expresa, sino a todas las cosas que emanan precisamente de la naturaleza de la obligación, o que por ley pertenecen a ella".

57 CÓDIGO DE COMERCIO. "Artículo 871. Principio de buena fe. Los contratos deberán celebrarse y ejecutarse de buena fe y, en consecuencia, obligarán no solo a lo pactado expresamente en ellos, sino a todo lo que corresponda a la naturaleza de los mismos, según la ley, la costumbre o la equidad natural."

58 Sobre el principio de la buena fe contractual y la integración de los contratos mediante el reconocimiento de los elementos que hacen parte de su naturaleza es muy valioso consultar las siguientes obras: SOLARTE RODRÍGUEZ, Arturo. La buena fe contractual y los deberes secundarios de conducta. En: Revista Vniversitas $\mathrm{N}^{\circ} 108$ de diciembre de 2004. Bogotá. Editorial JAVERGRAF-Pontificia Universidad Javeriana. 2004. p 283-315.; MÚÑOZ LAVERDE, Sergio. El principio de buena fe y su incidencia en la interpretación del contrato. Nulidad de las cláusulas abusivas en el derecho colombiano. En: Realidades y Tendencias del Derecho en el Siglo XXI. Derecho Privado. Tomo IV Volumen 1. Bogotá. Editorial Temis S.A. - Pontificia Universidad Javeriana. 2010. p 211 a 245. ISBN (978-958-35-0799-1); MARTÍNEZ CÁRDENAS, Betty Mercedes. Buena fe en la interpretación del contrato de seguro. En: Realidades y Tendencias del Derecho en el Siglo XXI. Derecho Privado. Tomo IV Volumen 1. Bogotá. Editorial Temis S.A. - Pontificia Universidad Javeriana. 2010. p. 674 a 688. ISBN (978-958-35-0799-1). 
durante la vigencia de la póliza que pudiera dar lugar a una reclamación futura, no reviste mayor reparo o discusión teórica por cuanto se trata de una estipulación contractual totalmente fundamental para la debida operatividad en este tipo de seguros, puesto que su incorporación evita los absurdos y peligrosos vacíos de cobertura. Adicionalmente, su aplicación práctica no requeriría mayor explicación o detalle en el texto contractual, ni estaría sujeta a ningún condicionamiento o requisito adicional diferente de cumplir en estricta forma con la debida notificación o reporte por escrito de tales circunstancias a la compañía de seguros.

Por el contrario, tratándose del periodo extendido de reporte, puede existir bastante resistencia y argumentos en contra de su calificación como un elemento de la naturaleza. Pues, a diferencia de lo que acontece con la prerrogativa de notificación o reporte de hechos conocidos durante la vigencia de la póliza, el periodo extendido de reporte o para notificaciones se ha concebido en la práctica como una cobertura adicional, que por tal razón está sujeta a la verificación de una serie de requisitos que normalmente son consignados con gran detalle en las pólizas de seguros. Por ejemplo, para acceder al periodo extendido de reporte es indispensable hacer de manera expresa la solicitud al asegurador, cumplir con una serie de condiciones y especialmente proceder al pago de una prima adicional que ha sido preestablecida en las condiciones particulares de la póliza.

En la práctica, en caso de silencio del texto contractual en torno a la posibilidad de adquirir un periodo extendido de reporte, será muy complicado considerar que dicha prerrogativa se encuentra incorporada implícitamente en el contrato, puesto que en ningún lugar fueron determinados sus principales características, como lo son su extensión temporal, su precio y en general todas las demás condiciones ligadas a su otorgamiento. Sin tan siquiera intentar negar o rebatir esa notable dificultad práctica, se considera que el verdadero elemento de la naturaleza del contrato, en este caso, no es tanto que se entienda incorporado en el seguro de responsabilidad bajo la modalidad "claims made" un determinado o específico periodo extendido de reporte, sino que exista de suyo la posibilidad de que el tomador $\mathrm{y} / \mathrm{o}$ asegurado pueda solicitar su otorgamiento y acceder sin mayores dificultades al mismo, estando por consiguiente el asegurador obligado a otorgarlo, claro está, bajo unas condiciones que deberán ser acordadas por las partes, pero que sin embargo no podrán distar de los usos y costumbres que se practiquen en el sector asegurador para ese tipo de seguros y actividades aseguradas. 
Sobre estas dos prerrogativas, debe reconocerse que en Colombia todos los clausulados generales de seguros de D\&O conocidos las incorporan sin falta y lo hacen además de manera muy similar, casi uniforme, con la salvedad, claro está, de los precios y vigencias del denominado periodo extendido de reporte, que, sin lugar a dudas, variarán en gran medida de compañía en compañía. Infortunadamente la inclusión de este tipo de prerrogativas en los condicionados generales no se verifica en otros tipos de seguros de responsabilidad civil bajo la modalidad "claims made" de la misma forma que pasa sin falta en los textos de D\&O, lo cual como dijimos, dificultará en la práctica el ejercicio de la prerrogativa del periodo extendido de reporte.

Como seguirá siendo comentado a lo largo del presente escrito un sistema de seguros "claims made" se puede tornar excesivamente restrictivo y lesivo de los intereses del tomador, asegurado y beneficiario, por no calificarlo de inequitativo e inútil, cuando no se verifica una debida conjugación de ciertas cláusulas e instituciones que deben acompañar necesariamente la modalidad de cobertura de responsabilidad civil por base reclamación. Se insiste, que así los contratos de seguro de responsabilidad civil bajo la modalidad "claims made" guarden silencio sobre la incorporación de las anteriores prerrogativas de cobertura prospectivas, por virtud de su naturaleza contractual y del cardinal principio de la buena fe contractual, las mismas se entenderán incorporadas por defecto y podrán hacerse valer dichos derechos conforme la extensión y alcance comentado.

\subsection{Las cláusulas "claims made" zanjan cualquier discusión en torno a la póliza que deberia afectarse en aquellos casos en los cuales la realización del hecho dañoso no coincide con la producción y manifestación del daño}

Bajo el esquema de ocurrencia pura, y muy a pesar de las definiciones legales, jurisprudenciales y la ayuda doctrinal, ha sido muy usual que se discutiera cuándo se verificaba efectivamente el siniestro y cuál debía ser efectivamente la vigencia del seguro afectada. Esa discusión se presentaba con frecuencia en aquellos casos en los cuales había riesgos continuados, o constantes hechos externos, periodos de latencia, que no 
permitían conocer con certeza cuál de ellos había sido el que efectivamente había generado el daño padecido por la víctima. ${ }^{59}$

Muchas veces los mencionados hechos se producían sucesivamente en diferentes vigencias del seguro, de manera que no era simple escoger un solo momento para calificarlo exclusivamente como fecha del siniestro y con ello permitir que fuera esa y únicamente esa póliza de seguro que se afecte con la pérdida. Piénsese, por ejemplo, en el caso de la asbestosis en el cual hubo constantes exposiciones por parte de los individuos con dicha materia, o en el caso de los medicamentos famosos antes mencionados Talidomida, DES, Bendectin, en los cuales se realizaba un consumo reiterado en el tiempo que impedía que se pudiera determinar a ciencia cierta cuándo se había producido efectivamente el daño, pues solo era posible conocer cuándo había sido el primer uso del medicamente y cuando se había manifestado por primera vez la enfermedad, pero sin tener mayores pistas sobre el enorme espacio de tiempo intermedio entre dichos extremos.

Tal complejidad llevó a que, en muchos casos, los jueces norteamericanos aplicaran novedosos criterios, denominados como el principio del "deep pocket", y ante la manifiesta dificultad de seleccionar una póliza de seguro para afectar decidieran, en aras de proteger a las víctimas y a los asegurados, afectarlas todas haciendo solidariamente responsables de la pérdida a todas las aseguradoras que hubieran estado presentes entre el momento del primer contacto e incluso la fecha de reclamación del perjuicio, tal como aconteció en tratándose de la asbestosis. En otras ocasiones llegaron al extremo de acumular todas las sumas aseguradas de las diferentes pólizas existentes como una medida aún más garantista de los intereses del asegurado y las víctimas. ${ }^{60}$

Incluso, superada la dificultad en torno a la definición del momento del siniestro, a través de la aplicación de la teoría del hecho dañoso, persistía el problema atinente a la prescripción de la acción directa de la víctima contra el asegurador, pues no tenía mucho sentido que dicho cómputo extintivo empezara a contar desde el acaecimiento del hecho

59 DÍAZ-GRANADOS. OP. Cit. p. 186. "El sistema ocurrencia genera inconvenientes en la hipótesis de siniestros tardios que no son fáciles de ubicar en el tiempo. A veces es imposible identificar el momento del daño y, por consiguiente, la póliza que lo cubra”. 
dañoso del asegurado, como ordena el artículo 1131 del Código de Comercio, si aún no se había manifestado el daño. ${ }^{61}$

También carecería de lógica que pudiera encontrarse prescrita la acción directa en cabeza de la víctima, cuyo término de extinción comienza desde la aparición del hecho externo imputable al asegurado, cuando aún pasados cinco años la víctima beneficiaria del seguro desconocía la efectiva generación o producción del daño. ¿Cómo podría lógicamente seguir posponiéndose un término extraordinario de prescripción que, como se ha sostenido, no se suspende, si no se pudiera afirmar que la fecha del siniestro no debería ser necesariamente aquella en la que se verificó el hecho imputable al asegurado, sino realmente aquella en que se produjo efectivamente el daño?

La modalidad de ocurrencia pura ha tenido y seguirá teniendo siempre inmersa la compleja disyuntiva entre producción del siniestro y exigibilidad de la obligación indemnizatoria a cargo de la aseguradora. Dificultad que, sin lugar a dudas, no tiene cabida en materia de seguros por reclamación en los cuales resulta evidente el momento de la configuración del siniestro por ser un evento indiscutible aquel de la petición indemnizatoria o reclamación judicial o extrajudicial por parte de la víctima al asegurado o a su asegurador. En lo que respecta al inicio del cómputo del término prescriptivo tampoco habrá dificultad, porque será la fecha en que se produzca la reclamación, momento configurativo del siniestro, la que dé inicio al cómputo de los términos prescriptivos, tal y como será revisado con mayor detalle más adelante.

\subsection{La desprotección del consumidor (tomador y asegurado) y de las victimas pues sin lugar a dudas se trata de un esquema de aseguramiento más restrictivo que el tradicional por ocurrencia pura}

El profesor Waldo Sobrino ${ }^{62}$ denuncia lo que considera el principal inconveniente que traen consigo dichas cláusulas: “(...) el argumento central en contra claims made es justamente la principal ventaja para las compañías de seguros: la desprotección del asegurado y de la víctima, dado que, para que tenga cobertura, no solamente el hecho

61 DÍAZ-GRANADOS. Op. Cit. p. 177.

62 SOBRINO. Waldo Augusto. Seguros y responsabilidad civil. Buenos Aires. Editorial Universidad. 2003. p. $67-68$. 
generador debe ocurrir durante la vigencia de la póliza de seguros, sino que, además, el reclamo de la víctima se debe formular durante la vigencia de la póliza uno o dos años posteriores a la finalización del seguro. Nótese que la cláusula claims made produce una especie de anarquía legal para los consumidores de seguros, dado que dos de los principales participantes de esta cuestión se van a ver absolutamente desprotegidos. En efecto, por un lado, el asegurado (por ejemplo, un médico) no va a tener ningún tipo de respaldo económico y, por el otro, las víctimas muy probablemente no van a tener a quién cobrarle."

La doctrina es prácticamente unánime al afirmar que el sistema "claims made", al reducir sustancialmente la exposición temporal de los aseguradores deja en muchos casos casi que, desprotegidos a los consumidores, pues en mayor o en menor grado y dependiendo del esquema o tipo de "claims made" contratado, habrá una mayor propensión para que ciertos hechos se queden huérfanos de cobertura y conviertan en nugatoria la prestación indemnizatoria a cargo del asegurador.

El respetable pensamiento de varios doctrinantes es magistralmente sintetizado por el profesor Jaramillo ${ }^{63}$ en las siguientes líneas:

"Es pues la consabida desprotección en que el tomador-asegurado y las víctimas pueden llegar a encontrarse, muy especialmente si el contrato se pacta en la más angosta de las modalidades puras, ya mencionada (todo durante la vigencia: la realización y manifestación del daño, su notificación y la reclamación) la piedra de toque de las profundas reservas expresadas por muchos en torno a las cláusulas "claims made". Incluso, no sin razón, se hable de "desnaturalización del contrato" en tales circunstancias, o de "vaciamiento contractual" sin perjuicio de otras voces que, en adición, aluden a una meridiana abusividad negocial, como se señalará (cláusula abusiva) y hasta de ostensible inconstitucionalidad. En consonancia con la supraindicada desprotección, tales voces, dichas protestas, unas más airadas que otras, refieren a que ellas se tornan ilusorias (GENEVIEVE VINEY), peligrosas (IYVONNE LAMBERT) y onerosas (FERNANDO SÁNCHEZ CALERO). Y otros expresan que con ellas se desatiende a los asegurados (MARÍA DE LOS ÁNGELES CALZADA), que ellas se erigen en la concesión injustificada de una ventaja sin precedentes para el gremio asegurador, gravemente atentatoria contra el derecho de los asegurados, aun en condiciones en que, dados los términos de prescripción de las acciones de responsabilidad civil extracontractual (ANDRÉS ORDÓÑEZ), que ellas afectan las expectativas del asegurado y la víctima (LUIS ALBERTO BOTERO, PATRICIA JARAMILLO Y FERNANDO RODAS), que son ilícitas (RUBÉN STIGLITZ), diabólicas (WALDO SOBRINO) desastrosas (MURIEL CHAGNY y LOUIS PERDRIX), un engendro jurídico (FERNANDO REGLERO CAMPOS), una trampa creada por los aseguradores

63 JARAMILLO. Op. Cit. p. 355 - 356. 
que hace peligrar a la propia institución del seguro de responsabilidad civil, cuya preceptiva es una barbaridad técnica y hasta un atentado contra el buen castellano (MARIANO IZQUIERDO TOLSADA), entro otros adjetivos..."

Sin perjuicio de que muchas de las críticas entabladas en contra del sistema "claims made" puedan ser en gran medida justificadas, lo cierto es que no puede incurrirse en la ligereza de satanizarlo a toda costa. Se considera sin atisbo de dudas que, si dicho esquema de cobertura es empleado de manera adecuada, combinando y reconociendo una serie de cláusulas y parámetros técnicos mínimos, puede brindar una satisfactoria cobertura a los asegurados e igualmente a sus víctimas, sin que tuviera que hablarse de enormes vacíos de coberturas, de falacias, ilusiones, etc.

Como acertadamente opina Miranda Suárez con un criterio ecuánime y libre de partidismos a favor o en contra del sistema "claims made":64 "(...) la delimitación de la cobertura con arreglo a criterios que incorporan la reclamación como elemento del siniestro es un adecuado y legítimo medio de seguridad frente a los siniestros tardios, pero su aplicación estricta resulta de una rigidez excesiva de ahí que su viabilidad y eficacia deba producirse en combinación con otros principios como el de ocurrencia y sea de vital importancia para su validez y correcta estipulación de un razonable periodo de cobertura ya sea retroactivo, ya sea post contractum".

En esa misma línea se estima, que para un adecuado funcionamiento de las cláusulas "claims made" deberán coexistir los siguientes parámetros mínimos que harían funcionar sin contratiempos y de forma razonable dicho sistema:

- Periodo retroactivo, que por regla general deberá ampliarse con cada sucesiva renovación.

Para la primera póliza bajo la modalidad por reclamación que se expida puede no ser necesaria una cobertura de hechos pasados, pues como ya explicó líneas atrás, lograr cobertura retroactiva es un beneficio que puede desprenderse de la estructura de las pólizas "claims made" pero que no resulta indispensable en aras de proteger los intereses del asegurado. Ello porque muchas veces puede tratarse de una actividad eco-

64 MIRANDA SUÁREZ. Op. Cit. p. 113. 
nómica nueva o simplemente de un cambio en la administración de riesgos en el que se opte por pasar de una modalidad por ocurrencia pura a un esquema por reclamación. Además, siendo precisamente eso un beneficio, no podría constreñirse a la aseguradora para que lo otorgara de arranque.

Sin perjuicio de lo anterior, lo que sin duda es indispensable, es que a medida que se renueve con la misma aseguradora el producto "claims made" se siga dando cobertura a reclamaciones que puedan tener origen en hechos ocurridos a partir del inicio de la primera póliza contratada. ${ }^{65}$ Cada renovación anual debería sumar un año más de retroactividad so pena de empezar a dejar vacíos, puesto el sistema "claims made" está diseñado para que cada póliza nueva entre a suplir lo que ya no fue amparado por sus predecesoras. La imposición de una aseguradora al tomador y/o asegurado para que renueve un seguro "claims made" sin retroactividad al inicio de cobertura debería ser absolutamente inaceptable.

- Inadmisibilidad del "claims made and reported"

Como será revisado en mayor detalle adelante, es ilegal y por ende inaceptable, la gravosa exigencia de tener que notificar al asegurador durante la vigencia del seguro sobre la presentación de una reclamación contra el asegurado con el ánimo de poder configurar el siniestro. Para un adecuado sistema "claims made" debe ser suficiente que se haya producido una reclamación por parte de la víctima al asegurado o a su asegurador durante la vigencia de la póliza y que dicha reclamación tenga su origen o su causa en un hecho ocurrido durante la vigencia de la póliza o dentro del periodo de retroactividad pactado.

- Periodo extendido de reporte

Perdería gran parte de su efectividad un sistema "claims made" en el que no se permitiera la posibilidad de amparar reclamaciones futuras. La cobertura prospectiva puede resultar determinante cuando se contrate por última vez el seguro, ello por cuanto es normal que mientras dura o esté vigente una actividad económica se aseguren las consecuencias nocivas de dicha actividad, sin embargo una vez verificada la conclu-

65 BOTERO. La teoría y la práctica del seguro por reclamación o seguro claims made. Op. Cit. p. 11. 
sión de la misma, por cualquier factor que la pudiera ocasionar, ya no tendría sentido tener que seguir renovando constantemente el seguro hasta que se agotaran o hasta que prescribieran todas las posibles acciones que pudieran existir en cabeza de las víctimas contra el o los asegurados.

El doctor Bernardo Botero no sólo comparte que la prerrogativa en mención es un elemento connatural al seguro de responsabilidad civil bajo la modalidad "claims made" para garantizar su normal operatividad, sino adicionalmente afirma que se trata de una prerrogativa que en la práctica es uniforme y pacíficamente consagrada en los clausulados de seguros de D\&O. ${ }^{66}$

Con relación a la prerrogativa en mención, es aconsejable que el precio de la cobertura futura sea fijado desde el inicio por las partes para evitar de esa manera futuras controversias o discusiones sobre su cuantía, cuantía que fijada unilateralmente por la compañía de seguros podría utilizarse en la práctica como un mecanismo para disuadir al asegurado de adquirir dicha extensión o prerrogativa contractual.

- Notificación de hechos y circunstancias conocidas.

Siguiendo igualmente con el esquema de coberturas prospectivas es totalmente indispensable porque se desprende de la naturaleza misma de esta modalidad de seguro y, por ende, recomendable que a su vez se consigne en los condicionados generales, que todos aquellos hechos que sean conocidos por el asegurado y debidamente notificados al asegurador durante la vigencia de la póliza, siempre que de los cuales se

66 “No está por demás poner de presente que la provisión de un periodo adicional para notificaciones a que hemos venido haciendo referencia, el cual es otorgado en forma por demás generalizada en los seguros de responsabilidad civil de directores y administradores, generalmente conocidos como seguros de D\&O, pólizas que sin excepción se otorgan hoy en día bajo la modalidad de seguros "por reclamación" o claims made - tiene especial fundamento en el hecho de que en dichos seguros o modalidades de cobertura, al igual de lo que sucede en los seguros de vida y en los denominados seguros de cumplimiento, el siniestro no es siempre un hecho súbito e imprevisto sino que, bajo ciertas circunstancias resulta factible anticipar su ocurrencia, tal como sucede cuando una empresa presenta resultados negativos en sus operaciones, producto de decisiones equivocadas adoptadas por la junta directiva o la administración de la misma. De lo aqui consignado se desprende que para los seguros otorgados bajo la modalidad de claims made y muy especialmente para el seguro de responsabilidad civil de directores y administradores, la cláusula mediante la cual se establece un periodo adicional para notificaciones resulta ser de la naturaleza misma de la cobertura otorgada y, por lo tanto, imprescindible en toda póliza otorgada bajo la modalidad claims made, en la medida en que, como se anotó con anterioridad, con alguna frecuencia el siniestro, o sea la reclamación por parte del tercero al asegurado o al asegurador, resulta no ser un evento totalmente imprevisto y mal podría considerarse admisible que bajo tales circunstancias la cobertura pudiera expirar y aún menos se revocada por parte del asegurador.” Ibid. p. 13. 
pudiera esperar razonablemente una futura reclamación, estarán cubiertos por la póliza de seguro vigente al momento en que fueron reportados sin que importe para el efecto la fecha en que se realice efectivamente la reclamación por parte de la víctima al asegurado o a su asegurador.

La mencionada prorrogativa contractual es fundamental porque en principio el periodo extendido de reporte y la retroactividad ofrecida por las pólizas están diseñados para darle cobertura a hechos que no siendo conocidos por el asegurado terminen generando una reclamación de perjuicios en su contra. Recuérdese que las pólizas bajo la modalidad "claims made" por definición y, en aras de conservar su intención de amparar únicamente riesgos putativos y no hechos prácticamente cumplidos, establecen una exclusión que deja sin amparo los hechos y circunstancias pasadas relevantes que hubieren sido conocidas por el asegurado y de las cuales razonablemente se hubiere podido esperar que generarían a futuro una reclamación. Desconocer en forma expresa en los textos contractuales dicha previsión produciría serios y peligrosos vacíos de cobertura.

Compartiendo la misma línea argumentativa expuesta anteriormente, sobre el amparo de hechos y circunstancias conocidas notificadas por el asegurado a su asegurador, expresa el profesor Bernardo Botero que se trata de una prerrogativa que se desprende de la naturaleza misma del contrato de seguro de responsabilidad bajo la modalidad "claims made" y que su observancia contractual puede incluso llegar a ser más determinante que aquella atinente al periodo extendido de reporte. En sus palabras:

"Mal podría, por lo tanto, aceptarse que un evento sucedido durante la vigencia de una póliza otorgada bajo la modalidad claims made, resultare excluido cobertura bajo esta por razón de que la reclamación del tercero damnificado al asegurado o a la aseguradora, hubiese sido presentada una vez expirada la vigencia de la póliza o, aún peor, una vez revocada la misma por el asegurador, y que, a su vez, dicha reclamación, por corresponder a un hecho anterior a la iniciación de la vigencia de una nueva póliza y ser además conocido por el tomador o el asegurado, no tuviese, igualmente - como en efecto sucede-cobertura bajo esta última.

Ciertamente habría sido aconsejable que el legislador se hubiese ocupado de establecer la normatividad pertinente al respecto dentro de la regulación expedida con el objeto de otorgar viabilidad al seguro claims made o "por reclamación", pero la ausencia de dicha normatividad no constituye, en nuestro criterio, razón suficiente para excusar, en una póliza determinada, la ausencia de incorporación de la respectiva cláusula, cuando la misma es indispensable 
para la cabal operatividad de la cobertura y, además, de normal y generalizado otorgamiento por el mercado asegurador, según quedó ampliamente demostrado a lo largo del presente escrito" 67

Respetados los anteriores cuatro elementos en las coberturas bajo la modalidad "claims made" dicho sistema debería operar sin contratiempos, ofreciendo suficiente cobertura a favor de los asegurados y sus víctimas. Las anteriores pautas deberán ser estrictamente observadas también cuando se efectúe un cambio de compañía de seguros por parte de la entidad tomadora o del asegurado para prevenir eventuales vacíos.

\subsection{Declaración del estado del riesgo en los seguros de responsabilidad bajo la modalidad claims made - Exclusión de hechos y circunstancias previamente conocidas.}

La modalidad de cobertura prospectiva consistente en la notificación a la aseguradora del acaecimiento de hechos y circunstancias de las cuales se pudiera producir a futuro una reclamación, va normalmente de la mano con una exclusión, que es usual en todos los seguros de responsabilidad civil bajo la modalidad "claims made", en la cual normalmente se deja sin cobertura todos los hechos o circunstancias que fueron conocidas por el tomador y/o asegurados con anterioridad al inicio de vigencia. La exclusión en comento, simplemente dispone que, no se brindará cobertura a reclamaciones que se deriven de hechos o circunstancias conocidos por el tomador y/o asegurados con anterioridad al inicio de vigencia de la póliza siempre y cuando de los mismos se pudiera esperar razonablemente que a futuro se produciría una reclamación. ${ }^{68}$

El sistema "claims made" parte de la base o premisa de amparar, en principio, únicamente con efectos retroactivos "riesgos putativos", es decir supone que el asegurado no conoce hechos o circunstancias que razonablemente pudieran dar lugar a una reclamación bajo la póliza. Lo anterior, básicamente por dos razones fundamentales: a) evitar posibles fraudes por parte de la entidad tomadora y del asegurado a la compañía

67 Ibíd. p. 19.

68 Normalmente suele consignarse en los siguientes términos: "3.3. CIRCUNSTANCIAS O HECHOS CONOCIDOS: CUALQUIER CIRCUNSTANCIA O HECHOS, REALES O SUPUESTOS, PARA LOS QUE, PREVIAMENTE A LA FECHA DE CONTINUIDAD, UN ASEGURADO HUBIERA RAZONABLEMENTE PODIDO PREVER QUE DARÍA LUGAR A UNA RECLAMACIÓN." AIG Seguros. Op.Cit. 
de seguros y; b) porque los aseguradores no desean por regla general asumir riesgos muy altos, que pudieran estar casi que cumplidos dependiendo de las circunstancias.

El propósito de esta exclusión no es dejar sin cobertura absolutamente todos los hechos o circunstancias pasados que rodearon la operación de la entidad tomadora del seguro y, por ende, de los asegurados, sino únicamente aquellos hechos o circunstancias que fueron o debieron ser conocidos y, de las cuales razonablemente, se pueda esperar que se producirá una reclamación futura. Para que aplique esta exclusión, el conocimiento del hecho o circunstancia no tiene que ir hasta el punto de tener plena conciencia sobre una efectiva causación de un daño a un tercero, baste con saber que se incurrió de manera activa o pasiva en una conducta que podría calificarse como incorrecta, contraria al ordenamiento jurídico y que, por la dimensión de dicha actuación y/o por el momento o circunstancias en las que tuvo lugar, pudieran razonablemente esperarse reclamaciones a futuro.

El hecho de que la aplicación de la exclusión en comento tenga un importante ingrediente subjetivo, enmarcado en la razonabilidad o expectativa de que el hecho conocido pudiera derivar en una reclamación futura, se prestará, sin lugar a dudas para que, en la práctica, se produzcan muchos debates entre compañía de seguros y asegurado. La razonabilidad acerca de la posibilidad de recibir un reclamo sólo podrá ser analizada cuando el mismo fuere formulado y, la mayoría de las veces, su calificación dependerá del criterio de un juez o de un árbitro. Idéntico análisis deberá hacerse cuando el conocimiento de dichos hechos y circunstancias se haga para negar cobertura del seguro o para solicitar la declaración de nulidad relativa del contrato fundada en una reticencia o inexactitud al momento de declarar sinceramente el estado del riesgo.

Aunque, ese marcado tinte subjetivo que envuelve la presente exclusión pudiera llevar precipitadamente a cuestionar su validez jurídica, pensando en calificarla como abusiva o lesiva de los intereses del asegurado, lo cierto es que ella coincide con el ordenamiento jurídico que persigue, que en principio, por regla general tan solamente sea objeto de amparo, el denominado "riesgo putativo", de manera que eventos ocurridos en el pasado, que fueron conocidos por el asegurado y de los cuales se pudiera esperar razonablemente que se presentaría una reclamación estarán excluidos de protección por adentrarse en los terreros de la certeza, alejándose con ello de los predios de la incertidumbre, que enmarca y define el riesgo asegurable. 
Obviamente, con el objeto de no caer en un peligroso juego de desprotección del usuario o consumidor del seguro de responsabilidad civil, los hechos y circunstancias conocidos sí deberían estar cubiertos por vigencias anteriores del seguro pues debe recordarse que por regla general los seguros bajo la modalidad por reclamación, tienen previsto que se dará cobertura a aquellos hechos que sean conocidos durante la vigencia de la póliza por el asegurado y, de los que se espere razonablemente, pudieran dar lugar a futuras reclamaciones, siempre y cuando los mismos fueren notificados y avisados a la compañía de seguros durante la vigencia de la póliza.

Normalmente al momento de la declaración del estado del riesgo mediante el diligenciamiento del formulario de asegurabilidad, se deja constancia del conocimiento de hechos y circunstancias que pudieran dar lugar a futuras reclamaciones. Dichos hechos y circunstancias declarados son expresamente excluidos por los aseguradores por tratarse de riesgos muy gravosos y prácticamente cumplidos. ${ }^{69}$ Cuando el informe de hechos y circunstancias conocidos se hace en el curso de una renovación del seguro de responsabilidad, lo que se generará, es que dichas circunstancias notificadas queden amparadas bajo la vigencia que expira (es decir de aquella vigencia en la que fueron notificadas a la aseguradora), pero excluidas de protección para las vigencias futuras.

La no declaración de hechos y circunstancias conocidas al momento de contratación inicial del seguro o de sus sucesivas renovaciones, siempre que de los cuales se pudiera esperar razonablemente se produciría a futuro una reclamación, podría traer múltiples consecuencias negativas para el tomador/asegurado. Por ejemplo, la omisión culpable en la declaración de conocimiento de esos hechos relevantes por parte del tomador/asegurado podría ser enmarcada como una reticencia que generaría eventualmente la nulidad relativa del contrato de seguro conforme lo consignado en el artículo $1.058^{70}$ del Código de Comercio.

69 No obstante, como fue dicho anteriormente en este trabajo nada impide que mediante convención especial pueda levantarse puntualmente dicha exclusión y darle expresa cobertura a los hechos y circunstancias conocidos. Ello siempre a criterio y discreción del suscriptor del riesgo y siempre y cuando haya mediado solicitud expresa por parte del tomador/asegurado. Por ejemplo, podría dejarse un hecho conocido sin cobertura para algunos asegurados, pero no para los demás.

70 CÓDIGO DE COMERCIO. “Artículo 1058. <Declaración del estado del riesgo y sanciones por inexactitud o reticencia $>$. El tomador está obligado a declarar sinceramente los hechos o circunstancias que determinan el estado del riesgo, según el cuestionario que le sea propuesto por el asegurador. La reticencia o la inexactitud sobre hechos o circunstancias que, conocidos por el asegurador, lo hubieren retraido de celebrar el contrato, o inducido a estipular condiciones más onerosas, producen la nulidad relativa del seguro. Si la declaración no se hace con sujeción a un cuestionario determinado, 
De otra parte, cuando la omisión de notificación o reporte de circunstancias y hechos conocidos relevantes se verifique con ocasión de la renovación del contrato de seguro, las consecuencias nocivas podrían ser, no sólo una eventual nulidad relativa del contrato por reticencia en la declaración del estado del riesgo, sino adicionalmente un posible limbo o agujero negro en la cobertura otorgada, dado que un hecho conocido que no es reportado, correría el riesgo de quedarse sin ninguna cobertura. Ello porque si no es reportado o notificado no sería cubierto por la póliza que expira e igualmente si se reporta posteriormente o de él deviene una reclamación, la compañía aseguradora podría demostrar que dicho hecho fue conocido anteriormente por el tomador/asegurado y excluirlo de cobertura o, simplemente dependiendo de su dimensión y talante, aniquilar la validez del contrato alegando una nulidad relativa por reticencia.

En relación con el deber de declaración sincera del estado del riesgo, es pertinente mencionar que hay seguros colectivos de responsabilidad en los cuales normalmente los formularios de asegurabilidad son diligenciados únicamente por el tomador del seguro sin involucrar individualmente a todos los futuros asegurados, como pudiera acontecer en los seguros de D\&O, que son normalmente adquiridos por la sociedad administrada (entidad tomadora) por cuenta de sus administradores. En referencia a la declaración del estado del riesgo por parte de la sociedad tomadora de un seguro colectivo y, específicamente acerca del eventual conocimiento que pudieran tener algunos de sus funcionarios y órganos sociales, de hechos y circunstancias de las que pudiera esperarse razonablemente en el futuro devendrían en una reclamación ha indicado el autor español Antonio Roncero ${ }^{71}$ :

"En todo caso, la asunción por la sociedad de la posición de tomador determina importantes consecuencias y plantea algunos problemas tanto desde la perspectiva de la relación aseguradora como desde un plano estrictamente

la reticencia o la inexactitud producen igual efecto si el tomador ha encubierto por culpa, hechos o circunstancias que impliquen agravación objetiva del estado del riesgo. Si la inexactitud o la reticencia provienen de error inculpable del tomador, el contrato no será nulo, pero el asegurador solo estará obligado, en caso de siniestro, a pagar un porcentaje de la prestación asegurada equivalente al que la tarifa o la prima estipulada en el contrato represente respecto de la tarifa o la prima adecuada al verdadero estado del riesgo, excepto lo previsto en el artículo 1160. Las sanciones consagradas en este artículo no se aplican si el asegurador, antes de celebrarse el contrato, ha conocido o debido conocer los hechos o circunstancias sobre que versan los vicios de la declaración, o si, ya celebrado el contrato, se allana a subsanarlos o los acepta expresa o tácitamente."

71 RONCERO. Op. Cit. p. 11. 
jurídico-societario. Así, desde la primera perspectiva, ello implica que la sociedad asumirá "las obligaciones y deberes que derivan del contrato... salvo aquellos que por su naturaleza deban ser cumplidos por el asegurado" (art. 7 LCS).

En la suscripción del contrato, la sociedad-tomadora podrá actuar por medio de sus administradores lo cual, en el caso (frecuente en la praxis) de que la póliza excluya la cobertura en relación con reclamaciones que versen sobre hechos acaecidos con anterioridad a su entrada en vigor y conocidos por el tomador, plantea la cuestión de determinar si el conocimiento por un administradorasegurado del hecho que provoca la reclamación debe entenderse que implica conocimiento por la propia sociedad-tomadora y, en consecuencia, determina la no cobertura de la misma; en principio, el conocimiento de un hecho dañoso por uno o varios administradores asegurados excluirá la cobertura de la reclamación dirigida contra éstos pero no la dirigida contra administradores que desconociesen la existencia del mismo, sin que pueda estimarse que el conocimiento individual del hecho dañoso por uno o varios administradores implique que deba considerarse que la propia sociedad es conocedora del mismo."

Sin perjuicio del debate que pudiera existir con respecto a este último punto, es indispensable mencionar que todos aquellos hechos y circunstancias que declare conocer la entidad tomadora en el formulario de solicitud del seguro cuando contrate por primera vez la póliza quedarán exentos de cobertura, salvo que expresamente se haya pactado lo contrario por las partes contratantes del seguro. Por consiguiente, sería innecesario entrar a debatir si el asegurado afectado conocía o no dicha circunstancia. Cuando se trate de la renovación del seguro, la declaración expresa por parte de la entidad tomadora, generará que deban considerarse dichos hechos y circunstancias conocidas como debidamente reportadas a la compañía de seguros en aras de verse favorecidas con la cobertura prospectiva a la que se hizo mención en extenso líneas atrás.

Ahora bien, cuando dichos hechos no hayan sido declarados, tendrá que revisarse en detalle el conocimiento que el tomador y asegurados, tenían sobre ellos y, concretamente, dicho debate deberá centrarse sobre el conocimiento específico del asegurado que pretende afectar la póliza, pues no sería equitativo, ni tendría mucho sentido privarlo de cobertura por la simple circunstancia de que alguno de sus colegas sí tuvo conocimiento de ese hecho, pero decidió guardárselo exclusivamente para sí. Esta situación es reconocida por varios clausulados generales que para los seguros de D\&O consagran una cláusula normalmente denominada 
como "Cuestionario y divisibilidad de declaraciones" en la cual se reconoce la individualidad de cada uno de los asegurados y no se les imputan los conocimientos o declaraciones que poseían, en forma exclusiva, otros asegurados.

\section{CONFIGURACIÓN DE SINIESTRO EN LOS SEGUROS DE RESPONSABILIDAD CIVIL BAJO LA MODALIDAD CLAIMS MADE}

Partiendo de la base que para los seguros de responsabilidad bajo la modalidad "claims made", como fue ampliamente expuesto líneas atrás, el siniestro consiste en la reclamación que la víctima presente en contra del asegurado o de su asegurador, en este último supuesto en uso de la acción directa consagrada a su favor por el ordenamiento jurídico, es de suma importancia analizar qué hechos o circunstancias configuran el acaecimiento de una "reclamación", es decir qué debe considerarse por tal y cuándo se entiende temporalmente presentada o acaecida. ${ }^{73}$

72 Por ejemplo, el texto de ACE SEGUROS DE COLOMBIA S.A. Op. Cit. contiene una cláusula con el siguiente tenor: "16. Formulario de Solicitud y divisibilidad. Para emitir esta Póliza el Asegurador se ha basado en la información y declaraciones contenidas en la solicitud de seguro, Formulario de Solicitud, cuestionarios complementarios, estados financieros y demás información exigida para la suscripción y presentada al Asegurador antes de la iniciación de la vigencia y durante el Periodo Contractual. Dichas declaraciones son la base de la aceptación del riesgo y de los términos y condiciones de esta Póliza, y por lo tanto se considerarán como parte integrante de la misma.

Con relación a las declaraciones contenidas en el cuestionario de solicitud de seguro, cuestionarios complementarios, estados financieros y demás información exigida para la suscripción y sometidos a la Compañía, tales cuestionarios serán considerados independientes para cada Asegurado en el sentido de que ninguna afirmación ni declaración o conocimiento poseído por cualquier Asegurado será imputado a ningún otro Asegurado a los efectos de determinar si existe cobertura bajo esta Póliza."

73 Al respecto, en referencia a los seguros de D\&O, que normalmente operan bajo esta modalidad, indica el profesor español Antonio Roncero: "Con frecuencia en las pólizas del seguro de responsabilidad civil de administradores de sociedades anónimas, el siniestro se define como la reclamación realizada por un tercero contra el asegurado en exigencia de su responsabilidad, a la vez que se determina el período de vigencia material del seguro tomando en consideración el momento de realización de la reclamación (véanse FERNÁNDEZ DEL MORAL, El seguro, pp. 189 y ss.; PÉREZ CARRILLO, pp. 274 y ss.; SÁNCHEZ CALERO, El seguro, pp. 411 y ss.). (...) La vinculación de la prestación del asegurador a la reclamación del perjudicado realizada dentro de un determinado periodo exige definir qué se entiende por "reclamación" (y, en particular, si es suficiente cualquier clase de exigencia o requerimiento para entender formulada una reclamación o si, por el contrario, es necesario que la misma se refiera al pago de una compensación económica) y a quién ha de formularse la misma (básicamente, al asegurado o a la sociedad tomadora) en relación con lo cual debe tomarse en consideración la posibilidad de acción directa que el artículo 76 LCS reconoce al perjudicado contra la compañia aseguradora (posibilidad que generalmente es ignorada en las pólizas que se ofrecen en nuestro mercado asegurador: vid. SÁNCHEZ CALERO, El seguro, p. 413). Asimismo, entendemos que el art. 73 LCS únicamente autoriza la vinculación de la prestación del asegurador a la reclamación del perjudicado realizada dentro del período de vigencia material del 


\subsection{Definición de reclamo}

Las pólizas de seguro de responsabilidad civil bajo la modalidad por reclamación, normalmente contienen definiciones en las cuales precisan qué se debe entender por reclamación y cuándo se entiende ella producida. Comúnmente se califica como reclamación ante el asegurado:

1. Toda demanda o proceso ante la jurisdicción civil, administrativa o arbitral.

2. Cualquier notificación o requerimiento escrito donde se demande la responsabilidad del asegurado por parte de la víctima.

3. Cualquier proceso penal iniciado en contra del asegurado.

4. Cualquier Investigación Oficial o Formal en la que se vincule al asegurado.

Debe tenerse presente que las reclamaciones pueden verificarse o presentarse en contra del asegurado, no sólo durante la vigencia de la póliza, sino también dentro del periodo adicional de notificación, denominado en algunos textos como periodo extendido de reporte, al cual se hizo referencia líneas atrás.

Durante dicho periodo podrán igualmente recibirse nuevas reclamaciones hechas al asegurado así haya expirado naturalmente la vigencia del seguro contratado, siempre y cuando los hechos que den lugar a dicha reclamación hubieren ocurrido durante la vigencia de la póliza o del periodo de retroactividad convenido, pero en todo caso antes de la expiración de la póliza contratada. Las reclamaciones que se reciban durante el periodo extendido de reporte contarán con plena cobertura, tal y como si hubieran sido presentadas durante la última vigencia contratada de la póliza.

Dados los escasos fallos que existen en nuestro país, en relación con los seguros de responsabilidad civil bajo la modalidad claims made, resulta ilustrativo mencionar que la Corte Suprema de Justicia en fallo del 15 de diciembre de 2.006, por motivos de técnica de casación, al considerar que el recurso propuesto incluía afirmaciones nuevas no tratadas durante el curso de la litis, se abstuvo de analizar de fondo si

seguro pero no a la notificación de esta al asegurador por lo que, en consecuencia, no serán válidas aquellas cláusulas que exijan que no solo la reclamación sino también su notificación al asegurador se haya realizado dentro del periodo de vigencia material del seguro (que, no obstante, se incluyen en algunas pólizas; vid. SÁNCHEZ CALERO, El seguro, p. 413)”. RONCERO. Op.Cit. Págs. 26 y 27. 
efectivamente le asistía razón al recurrente cuando alegaba que no podía haber cobertura alguna en la póliza de D\&O objeto de examen por cuanto la reclamación presentada a la aseguradora (curiosamente motivada en un llamamiento en garantía) fue efectuada y notificada a ésta con posterioridad a la fecha de expiración de la póliza "claims made" que fue expedida.

El recurrente, Previsora Seguros, manifestó en su recurso de casación que la reclamación a la compañía de seguros debió formularse entre el $1^{\circ}$ de octubre de 1998 y el 30 de septiembre de 1999, y concluye que al producirse el 2 de febrero de 2001, con la notificación personal de su representante legal, es decir, más de un año y medio después de haber expirado la vigencia de la póliza, la condición de la que pendía la obligación del asegurador se encontraba fallida en los términos del artículo 1539 del C.C. La Corte como ya mencionamos se abstuvo de pronunciarse sobre el fondo de la censura. ${ }^{74}$

Pasaron siete años para que la Corte Suprema de Justicia tuviera nuevamente oportunidad para pronunciarse sobre la operatividad de las cláusulas “claims made”, lo cual hizo finalmente mediante providencia del 18 de diciembre de 2013, en la cual se discutió la procedencia del cobro de honorarios de abogados al amparo de la cobertura de gastos

74 CORTE SUPREMA DE JUSTICIA. Sala de Casación Civil. Sentencia del 15 de diciembre de 2.006. MP. Jaime Alberto Arrubla Paucar. Exp. 52001-31-03-004-2000-00276-01 “Ciertamente, como anota la censura, la cláusula primera de las condiciones generales de la póliza, al definir su cobertura, determina que por ella se amparan "las reclamaciones formuladas durante la vigencia de esta póliza, y que no hayan sido presentadas con anterioridad a la iniciación de la misma, por uno o varios terceros con motivo de los perjuicios que causen los asegurados y de los cuales sean responsables civilmente de acuerdo con la ley, en virtud de haber incurrido en uno o varios actos incorrectos según la definición contenida en las condiciones de esta póliza”. Establece así que cubre las reclamaciones que satisfagan dos condiciones distintas: a) que se formulen durante la vigencia de la póliza, y b) que no se hubieren presentado antes de comenzar el término de duración del contrato. Luego si el Tribunal solo se ocupó de la última, al dejar por establecido que la demanda se presentó cuando ya estaba en curso el periodo de vigencia de la póliza, pero omitió toda alusión y análisis sobre la primera, puesto que nada expresó sobre la estipulación contractual por la cual se ampararon solamente "las reclamaciones formuladas durante la vigencia" del contrato, ni sobre el cumplimiento de tal condición, so pretexto de haber examinado aquella, no puede hostigársele por lo que no hubiere visto en relación con esta, pues aunque se trate de situaciones ligadas a un mismo aspecto, como es la cobertura de la póliza, constituyen, a la postre, circunstancias distintas. (...)

Coligese entonces que si la problemática en la que se asienta el cargo no toca con la determinación del derecho objetivo que incide en la solución del caso, órbita en la que ninguna limitante refrenaría su examen, ni constituye, por otro lado, asunto que contrarie el orden público o que oficiosamente se haya involucrado en el debate, como se alega, tratándose por el contrario de una cuestión de hecho que se alega ex - novo, como quiera que no formó parte de los argumentos defensivos de la recurrente, quien solo lo somete a consideración de la Corte con ocasión del recurso, ninguna duda queda en cuanto a que se trata de un medio nuevo, inidóneo para servir de soporte al recurso y allanarle el camino al triunfo. (...)

2. El cargo, por lo que queda dicho, no prospera." (Subraya por fuera del texto original). 


\section{de defensa concedida por una póliza de D\&O. En esta ocasión la Corte} en forma acertada reconoció que para que haya amparo bajo una póliza de responsabilidad bajo la modalidad claims made, debe producirse la reclamación durante la vigencia de la póliza de seguro ${ }^{75}$.

En dicho fallo, la Corte igualmente señaló que, en caso de existir múltiples reclamaciones, debería tomarse como detonante de la cobertura la primera que se hubiera producido, de manera que no era dable afectar, con base en un mismo hecho, dos pólizas de seguro con diferentes vigencias. En palabras del Alto Tribunal: ${ }^{76}$

“(...) La labor comparativa lo condujo a precisar que "como la citación oficial al actor para rendir versión libre ante la Contraloría General de la Nación se surtió el 18 de febrero de 1999 (f. 70 y 534 C.1) ésta resulta ser el siniestro y por ende la 'reclamación', hallándose para tal data vigente la póliza con la Aseguradora Colseguros S.A.- la que rigió hasta el 8 de marzo de 1999- solo hacia ella le asiste la legitimación en la causa por activa al actor Henry Ávila Herrera y no para con la aseguradora La Previsora S.A., cuya póliza comenzó a regir a partir del 8 de marzo de 1999, cuando ya había ocurrido el reclamo al asegurado y por ende no puede cobijarle, lo que se halla a tono con lo estipulado en las disposiciones de reclamos, literal b) última parte, en donde se indició que 'Una vez se haya dado la noticia como se estipula en el numeral 6 b) anterior, cualquier reclamo posterior será considerado que se hizo durante la vigencia del seguro '”. (...)

d.-) Las dos pólizas, a pesar de que cubrían los mismos riesgos, lo que es posible al tenor del artículo 1092 del Código de Comercio que trata la pluralidad o coexistencia de seguros, se excluían en los términos convenidos como lo advirtió el ad quem, porque: (i) Todas las comunicaciones dirigidas por Henry Ávila Herrera a las aseguradoras, informando sobre la citación a diligencias ante la Fiscalia, algunas de las cuales llegaron a etapa de juicio penal, así como las investigaciones por responsabilidad fiscal ante la Contraloría y otros entes de

75 CORTE SUPREMA DE JUSTICIA. Sala de Casación Civil. Sentencia del 18 de diciembre de 2013. MP Fernando Giraldo Gutiérrez. Rad. N 11000131030412000-01098-01. Al respecto opinó la Corte: "6.- A pesar de que en términos del artículo 1131 del Código de Comercio, modificado por el 86 de la Ley 45 de 1990, en "el seguro de responsabilidad se entenderá ocurrido el siniestro en el momento en que acaezca el hecho externo imputable al asegurado", cuando la responsabilidad se predica de directores o funcionarios, la póliza que la cobija suele contar con la particularidad de ser por reclamación o "claims made", por cuanto la cobertura está delimitada temporalmente por distintas modalidades y combinación de cláusulas. El artículo $4^{\circ}$ de la Ley 389 de 1997 establece que: (...) De conformidad con dicho precepto, pueden presentarse las siguientes situaciones: a.-) Que coincidan dentro de la vigencia tanto el hecho dañoso, como la reclamación de la víctima al asegurado o la aseguradora. b.-) Que el hecho dañoso sea anterior a la vigencia, pero el reclamo se presente dentro de ésta. c.-) Que se cubran sucesos acaecidos durante la vigencia, pero el reclamo se haga por fuera de la misma, en un plazo preestablecido para notificaciones. El primer caso es connatural al convenio, pero los otros dos requieren de pactos expresos, claramente delimitados, cuya interpretación exige del fallador un examen estricto y restringido, que impida extender los amparos a riesgos no cubiertos o dejar por fuera aquellos que sí lo están." 
control y vigilancia, tuvieron su génesis en la Auditoría que se le practicó al Banco del Estado y de que da razón el escrito de 11 de febrero de 1999, en el cual se previno que "en cumplimiento de la Ley 42 de 1993, informará a las autoridades competentes en lo financiero, administrativo, disciplinario y penal para que inicien, si asi lo consideran, la investigaciones que sean del caso en sus respectivos ámbitos de competencia" (folio 66, cuaderno 1). Por lo tanto, podría entenderse, como lo hizo,,,,,,,,,,,,,,,,,,,, el Tribunal, que constituían un solo "reclamo" o "reclamación”, así se hubieran ido presentando en diferentes fechas o en atención a las citaciones de que iba siendo objeto el promotor, independientemente de su dilación en el tiempo, pues, estaban "causalmente relacionados".(ii) Si bien la misiva de 11 de febrero de 1999 de la Contraloría General de la Nación encaja dentro del concepto de "cualquier comunicación escrita alegando un acto erróneo" y daba por sentado la apertura de diferentes trámites en contra del Directivo remitente, lo cierto es que la primera citación para rendir su versión sobre los hechos endilgados se dispuso al día siguiente, para ser llevada a cabo el 18 de los mismos mes y año, fechas todas en vigencia del contrato ajustado con Colseguros. Esta sola circunstancia dejaba por fuera de cualquier responsabilidad a La Previsora, máxime cuando entre las exclusiones que señaló esta última estaban el que "la indemnización o pago esté disponible de cualquier fuente, diferente a esta póliza" y sea "ocasionada por, o contribuida por, o a consecuencia de cualquier circunstancia existente antes de o a la fecha de iniciación de esta póliza y que los Directores o Administradores o la Compañía sabían que o que debieron razonablemente haber sabido, que daría lugar a una reclamación", como en este caso ocurrió."

El entendimiento sobre la operatividad de las cláusulas "claims made" realizado la Corte coincide con la lectura que ha hecho la doctrina y los tribunales de arbitraje en materia de seguros ${ }^{77}$, de manera que no cabrían reparos sobre el particular. El único aspecto, indicado por el Alto Tribunal, que no puede compartirse es el referente a la necesidad de aprobación previa por parte de la compañía de seguros de los gastos de defensa del asegurado, so pena de la pérdida del derecho al pago de la correspondiente indemnización, tópico que no es objeto del presente estudio, pero que no por ello, puede dejar de ser censurado como se ha venido haciendo de tiempo atrás. ${ }^{78}$

77 Laudo Arbitral Proyectar Valores S.A. Comisionista de Bolsa en Liquidación forzosa administrativa contra Cubb de Colombia Compañía de Seguros S.A. y Chartis Seguros Colombia S.A. Op. Cit. p. 48 - 55

78 Cfr. URIBE LOZADA, Nicolás. Régimen general de responsabilidad civil de los administradores de sociedades y su aseguramiento. Universidad Javeriana. Grupo Editorial Ibáñez. 2013. p. 438 - 442. 


\subsection{Notificación o reporte de la reclamación al asegurador}

Vale la pena preguntarse si para que opere la cobertura otorgada por los seguros de responsabilidad bajo la modalidad claims made ¿es suficiente únicamente con que se le presente la reclamación al asegurado o si es, adicionalmente necesario que se le notifique dicha circunstancia al asegurador?

De la lectura de algunos clausulados ofrecidos en el mercado colombiano ${ }^{79}$ se podría pensar que se está consagrando una modalidad de "claims made and reported", pues se exige en aras de proveer cobertura, que el asegurado notifique al asegurador la producción de la reclamación en su contra.

Sin perjuicio de lo consagrado en los diferentes clausulados es sumamente importante reiterar que las denominadas cláusulas "claims made and reported" son altamente restrictivas y pueden atentar severamente los derechos del asegurado, pues someten la protección ofrecida al asegurado al cumplimiento de una doble condición no prevista en el ordenamiento jurídico y en muchas ocasiones, de difícil verificación práctica, que la reclamación al asegurado tanto como la notificación de este hecho a la aseguradora se verifiquen durante la vigencia del seguro.

Debe recordarse que este tipo de cláusulas están proscritas en otros ordenamientos jurídicos por vulnerar los derechos del asegurado. Concretamente en España el tratadista Antonio Roncero considera que la condición "claims made and reported" es ilegal a la luz de lo consagrado en la Ley Contrato de Seguro dado que en ningún aparte de la normativa española se establece que para configurar el siniestro sea además necesaria la notificación de la producción de la reclamación al asegurador.

79 Por ejemplo, el texto de AIG SEGUROS expresa: "5.4. Notificación: Las coberturas bajo el presente contrato de seguro solo se otorgan con respecto a: (i) Reclamaciones presentadas por primera vez en contra de un Asegurado durante el Periodo de Vigencia del Contrato o el Periodo de descubrimiento si fuese aplicable, siempre que dichas Reclamaciones havan sido notificados a CHARTIS SEGUROS. (ii) Eventos de Crisis notificados a CHARTIS SEGUROS durante el Periodo de Vigencia del Contrato. Todas las notificaciones se deben dirigir a la dirección que se especifica en la Carátula y deberán incluir como referencia el Número de Póliza”. (Se resalta por fuera del texto original). AIG SEGUROS. Seguro de responsabilidad civil D\&O empresarial. Op. Cit. Por su parte Ace Seguros al regular el periodo adicional de descubrimiento indica en su texto: “9. PERIODO DE DESCUBRIMIENTO: La cobertura de esta póliza se extenderá a cubrir la Pérdida derivada de una reclamación que sea formulada por primera vez en contra del Asegurado y presentada por este al Asegurador durante esta extensión que se denominará Periodo de Descubrimiento (...)” (Se resalta por fuera del texto original). ACE SEGUROS DE COLOMBIA S.A. Seguro de responsabilidad para altos ejecutivos y miembros de junta directica. Ace D\&O. Op. Cit. 
En palabras del profesor Roncero ${ }^{80}$ que se comparten de lleno: "Asimismo, entendemos que el art. 73 LCS únicamente autoriza la vinculación de la prestación del asegurador a la reclamación del perjudicado realizada dentro del período de vigencia material del seguro pero no a la notificación de esta al asegurador por lo que, en consecuencia, no serán válidas aquellas cláusulas que exijan que no solo la reclamación sino también su notificación al asegurador se haya realizado dentro del período de vigencia material del seguro (que, no obstante, se incluyen en algunas pólizas; vid. SÁNCHEZ CALERO, El seguro, p. 413)”.

Como ya fuera mencionado, existen varios fundamentos también en el ordenamiento jurídico colombiano que podrían llevar a concluir que se estaría en presencia de una cláusula ilegal o como mínimo abusiva porque limitaría injustificadamente los derechos del asegurado. El artículo 4 de la Ley 389 de 1.997 claramente expresa que lo que marcará el inicio de la cobertura, es decir su detonación, será la reclamación presentada por la víctima, bien sea al asegurado o directamente al asegurador, de manera que una vez producida dicha reclamación se habrá verificado el riesgo asegurado y, conforme lo establecido en el artículo 1.072 del Código de Comercio, ya citado, se habrá producido el acaecimiento del siniestro.

Es fundamental reiterar que la normatividad colombiana no exige requisitos o condiciones adicionales para configurar el siniestro y que nazca a la vida jurídica la cobertura ofrecida por el contrato de seguro, de manera que mal harían las compañías de seguros si impusieran mayores requerimientos a sus asegurados para la configuración del mismo, máxime cuando, como acontece en este caso, se está en presencia de una modalidad de cobertura por definición más restrictiva y habilitada únicamente de manera excepcional para los seguros de responsabilidad civil. ${ }^{81}$

De hecho, según lo dispuesto en la regulación patria, el aviso o notificación a la aseguradora del siniestro es una obligación en cabeza del asegurado y/o beneficiario (art. 1075 C.de Co.) que deberá cumplirse

80 RONCERO. Op. Cit. p. 27

81 Sobre el particular es importante tener presente que se está hablando de un requisito adicional para el nacimiento de la obligación indemnizatoria a cargo de la aseguradora y no de los requisitos de exigibilidad de dicha obligación indemnizatoria previstos en los artículos 1077 y 1080 del Código de Comercio que imponen al asegurado o beneficiario del seguro la carga de la reclamación de dicha indemnización en la cual deberán acreditar tanto la ocurrencia del siniestro como su cuantía. Lo que se cuestiona en estas líneas es que se exige para el nacimiento de la obligación, que no para su exigibilidad, un específico reporte de dichas circunstancias a la compañía de seguros. 
una vez ocurrido este, pero nunca ha sido considerada como una condición precedente de responsabilidad o requisito adicional necesario para permitir el nacimiento de la obligación indemnizatoria en cabeza de la compañía de seguros.

Basados en lo anterior, sería válido preguntarse entonces ¿qué pasaría si el asegurado omitiese dar aviso a la aseguradora de la verificación de una reclamación en su contra? Conforme al ordenamiento jurídico colombiano tendrían cabal aplicación los artículos $1075^{82}$ y $1078^{83}$ del Código de Comercio que establecen primero que el asegurado está obligado a dar aviso informal al asegurador del acaecimiento del siniestro dentro de los tres días siguientes a su ocurrencia. En caso de incumplir con dicha obligación a su cargo, el asegurador podrá deducir del importe de la indemnización a su cargo todos aquellos perjuicios que lograre demostrar y que le hubieren sido causados por la omisión de aviso por parte del asegurado

En resumidas cuentas la omisión de notificación a la aseguradora del acaecimiento de una reclamación en contra del asegurado (omitimos conscientemente el evento en que la reclamación sea presentada directamente a la aseguradora porque la misma llevaría inmersa el efecto de su notificación) no puede conllevar a la pérdida del derecho a percibir la indemnización del siniestro a favor del beneficiario del seguro puesto que bajo la legislación colombiana la omisión de aviso de la ocurrencia del siniestro al asegurador (en este caso la falta de notificación de la producción de la reclamación) sólo es sancionada en los términos previstos en el artículo 1.078 del C.de Co, esto es facultando a la compañía de seguros para deducir al asegurado/beneficiario aquellos perjuicios que su comportamiento omisivo le hubiera generado.

Se comparte totalmente, la enfática posición sostenida por el doctor Bernardo Botero, quien vehementemente denuncia la ilegalidad de las mencionadas cláusulas "claims made and reported" frente al ordena-

82 CÓDIGO DE COMERCIO. "Artículo 1075. Aviso de la ocurrencia del siniestro. El asegurado o el beneficiario estarán obligados a dar noticia al asegurador de la ocurrencia del siniestro, dentro de los tres días siguientes a la fecha en que lo hayan conocido o debido conocer. Este término podrá ampliarse, mas no reducirse por las partes. El asegurador no podrá alegar el retardo o la omisión si, dentro del mismo plazo, interviene en las operaciones de salvamento o de comprobación del siniestro".

83 CÓDIGO DE COMERCIO. "Artículo 1078. Reducción de la indemnización por incumplimiento. Si el asegurado o el beneficiario incumplieren las obligaciones que les corresponden en caso de siniestro, el asegurador solo podrá deducir de la indemnización el valor de los perjuicios que le cause dicho incumplimiento. La mala fe del asegurado o del beneficiario en la reclamación o comprobación del derecho al pago de determinado siniestro, causará la pérdida de tal derecho". 
miento jurídico colombiano, no sólo porque las mismas en su criterio contravienen lo previsto en el artículo 1078 del C. de Co, situación ya denunciada, sino porque adicionalmente en su criterio, desconocen también las normas aplicables en materia de prescripción del contrato de seguro de responsabilidad civil. En sus palabras: ${ }^{84}$

"No resultan en nuestro criterio jurídicamente admisibles, a la luz del régimen legal colombiano, las denominadas pólizas claims made and reported, las cuales exigen para la existencia de cobertura que la reclamación, además de reportada al asegurado durante la vigencia de la póliza, lo sea así mismo al asegurador bien dentro del mismo término de vigencia de la póliza, o en un lapso adicional normalmente no superior a tres meses, contados a partir de la fecha de expiración de la vigencia consignada en póliza.

La cobertura otorgada en dicha forma claramente contraviene, en nuestro criterio dos normas de carácter imperativo relativas al contrato de seguro, consignadas en el código de comercio, a saber:

Por una parte, la norma sobre prescripción de las acciones derivadas del contrato de seguro de responsabilidad civil, consignada en el artículo 1131 antes citado, al supeditar la existencia de cobertura, o sea, eliminar la posibilidad para el asegurado de recibir indemnización alguna por un hecho de otra forma amparado, como consecuencia de no haber sido formulado el correspondiente reclamo al asegurador dentro de un término muy inferior del consignado en la citada norma para la prescripción de la acción respectiva.

Por otra parte, el primer inciso del artículo 1078, norma que establece las sanciones por incumplimiento de las obligaciones en caso de siniestro, entre las cuales no se incluye la pérdida del derecho a la indemnización por el hecho de que el asegurado, salvo mala fe, incumpla la obligación de dar aviso al asegurador, dentro de un cierto término establecido en el contrato, sobre un reclamo realizado por el damnificado. Dicha norma, de conformidad con el expreso mandato del artículo 1162 del varias veces citado Código de Comercio, es modificable únicamente a favor del tomador, asegurado o beneficiario."

Así lo reconoció igualmente la Corte Suprema de Justicia, en fallo del 31 de julio de 2014, en el cual consideró que el reporte tardío de la reclamación por parte del asegurado a la compañía de seguros no ocasionaba la pérdida del derecho a la indemnización a favor del asegurado, sino únicamente la deducción de aquellos perjuicios que el reporte tardío hubiera causado a la aseguradora:

“Ahora, a pesar de que dicho "reclamo» lo recibió la «asegurada» el «14 de septiembre de 2006», y no lo informó a la "aseguradora» de manera inmediata conforme lo exigido en el convenio en mención, sino hasta el «11 de diciembre

84 BOTERO. La teoría y la práctica del seguro por reclamación o seguro claims made. Op. Cit. p. 10-11. 
de 2006», el mismo no queda excluido del amparo, toda vez que fue allegado a la C........... D.. C............ D.. B........... «durante la vigencia de la póliza», la que valga recordar, abarcó desde el «30/11/2005 hasta el 30/11/2006», y según lo estipulado, es la "presentación del reclamo», el que se toma en cuenta para la configuración del «siniestro», supuesto este que se adecúa a la segunda hipótesis determinada en el precedente jurisprudencial antes reproducido para que opere la cobertura, toda vez que el hecho perjudicial aconteció el "2 de agosto de 2004» al efectuarse el "registro del acta de aprobación de la liquidación de la sociedad L... D.. B......... S.A.», en tanto que el "reclamo a la asegurada» se realizó hallándose en vigor el "contrato de seguro»

Cabe acotar, que a pesar de haberse realizado la notificación del «siniestro» a la «aseguradora», no con la celeridad pactada, esa situación no genera la pérdida del derecho, sino que podría producir las consecuencias señaladas en el artículo 1078 del Código de Comercio, el que faculta al «asegurador» para «deducir de la indemnización el valor de los perjuicios que le cause dicho incumplimiento»." ${ }^{85}$ (Se resalta por fuera del texto original)

Sin perjuicio de lo hasta aquí expuesto, es menester reconocer que la ausencia de notificación al asegurador del conocimiento de hechos y circunstancias conocidas por el asegurado durante la vigencia de las pólizas de las cuales se pudiera esperar razonablemente que se produciría una futura reclamación, sí podría tener el efecto de dejar huérfano de cobertura al asegurado, pues en este caso, el detonante de la cobertura otorgada es precisamente la notificación misma que se haga a la aseguradora. Como ha sido insinuado líneas atrás y se abordará con mayor detalle a continuación, la configuración del siniestro muta nuevamente y se brinda cobertura provisional aun cuando no haya habido reclamación alguna, en otras palabras, aun cuando no se haya verificado el riesgo asegurado.

\subsection{Notificación de hechos y circunstancias conocidas durante la vigencia de la póliza de las cuales pudiera derivarse razonablemente a futuro una reclamación - ¿Se modifica la definición del siniestro en los seguros "claims made"?}

Mención especial merece la prerrogativa connatural de los seguros "claims made", por virtud de la cual se establece que será un detonante de cobertura del seguro de responsabilidad civil, la notificación a la

85 CORTE SUPREMA DE JUSTICIA. Sala de Casación Civil. Sentencia del 31 de julio de 2014. Op. Cit. 
aseguradora de actos, hechos o circunstancias conocidos por primera vez por el asegurado durante la vigencia de la póliza y de los cuales se pudiera esperar razonablemente a futuro una reclamación en contra de este.

El aviso de dichos eventos anticipará la cobertura otorgada pues hará que los mismos sean amparados por la póliza vigente al momento en que se dé aviso al asegurador y, no por aquella, póliza futura que se pudiere encontrar en vigor cuando se presente efectivamente la requisición indemnizatoria al asegurado. Los hechos que pudieran dar lugar a la reclamación deberán haber ocurrido durante la vigencia de la póliza o con posterioridad al término de retroactividad pactado, para poder estar amparados por el seguro. ${ }^{86}$

Otra alternativa en la que se consigna la presente prerrogativa en los clausulados de seguro de D\&O es mediante su inclusión en la definición misma de reclamación. De tal suerte, se considera como reclamación, el aviso o notificación al asegurador de hechos y circunstancias que pudieran razonablemente dar pie a una reclamación futura. Tal es el manejo que sobre el particular dispensan Aseguradora Colseguros y Seguros Suramericana en sus condicionados. ${ }^{87}$

86 AIG SEGUROS. Op.Cit. "5.6. Reporte de Circunstancias: Cualquier Asegurado puede, durante el Periodo de Vigencia del Contrato, notificar a AIG SEGUROS, en la dirección que se indica en la Carátula, cualquier circunstancia que razonablemente pudiera dar lugar a una Reclamación. La notificación debe incluir las razones por las cuales se anticipa tal Reclamación, junto con todos los detalles, incluyendo las fechas, los actos y las personas involucradas".

87 Tanto en los clausulados de SURAMERICANA como de ALLIANZ COLSEGUROS, si bien no se consagra expresamente que se pueden entender amparados hechos conocidos durante el periodo extendido de reporte, lo cierto es que la definición de reclamación que contienen ambos clausulados, que por cierto es idéntica, incluye como reclamación misma el reporte de "hechos constitutivos de un eventual siniestro". Por ejemplo, el clausulado de Colseguros indica lo siguiente: "5.33.

RECLAMACIÓN: Toda demanda o proceso por la comisión de un Acto Incorrecto, iniciado en contra de las Personas Aseguradas en la jurisdicción civil, penal, administrativa o arbitral incluyendo: a) Cualquier notificación o requerimiento escrito en contra de las Personas Aseguradas que pretenda la declaración de que el mismo es responsable de un daño; b) Cualquier proceso penal iniciado en contra de las Personas Aseguradas o al que estas sean vinculadas, sujeto a las limitaciones que se establecen en las Exclusiones de esta póliza o; c) Cualquier procedimiento administrativo o investigación en contra de las Personas Aseguradas. Toda Reclamación derivada de, basada en, a la que se atribuya, o que pueda interpretarse como derivada de un mismo Acto Incorrecto será considerada como una sola Reclamación para los efectos de esta póliza. Respecto de hechos constitutivos de un eventual Siniestro que las Personas Aseguradas hubiesen conocido e informado a la Compañía durante la Vigencia de la póliza o del Periodo Adicional para Notificaciones, de los que razonablemente se espere que pudieren dar origen a una Reclamación y que efectivamente den con posterioridad origen a la misma, esta se considerará presentada en el momento en que tales hechos hayan sido informados por primera vez, siempre que la información suministrada a la Compañía especifique con claridad los motivos para prever que la Reclamación será presentada, con indicación detallada de las razones para ello, así como de fechas circunstancias y personas involucradas" (Se subraya por fuera del texto original) 
En muchos de los textos disponibles en el mercado no sólo se permite el reporte y notificación de hechos conocidos por primera vez durante la vigencia de la póliza, sino también de hechos y circunstancias conocidos durante el periodo extendido de reporte o de notificación al asegurador, siempre y cuando hubieran acaecido durante la vigencia del seguro o del periodo de retroactividad pactado. Tal es el caso por ejemplo del texto utilizado Chubb. ${ }^{88}$

Revisadas las diferentes redacciones bajo las que se consagra la facultad de darle cobertura a hechos o circunstancias conocidas por primera vez durante la vigencia del seguro o durante el término adicional para notificaciones es importante preguntarse ¿si a la luz de dichos textos se modifica nuevamente, en las pólizas “claims made” la definición de siniestro, dejando de ser este la reclamación misma y pasando a serlo, por lo menos en este caso puntual, el descubrimiento de un hecho y principalmente su subsiguiente reporte o notificación al asegurador?

Ofrecer una respuesta única y contundente a este interrogante, teniendo en cuenta las diferentes redacciones contenidas en los clausulados y la loable intención y propósito de esta figura, es sumamente complicado porque sin lugar a dudas se interna el intérprete en una espesa zona gris. Sin embargo, en aras de continuar este esfuerzo académico, se esbozarán dos posibles respuestas.

Una primera solución sería afirmar que en este particular caso se modifica nuevamente la definición o concepto de siniestro en las pólizas "claims made”, pues la verificación del riesgo asegurado, el gatillo o "trigger" que detona la cobertura ofrecida por el seguro, estará marcada por el aviso o notificación de un hecho relevante conocido al asegurador. Notificación que, necesariamente deberá tener lugar, durante la vigencia de la póliza o del periodo extendido de reporte. Bajo esta interpretación debe agregarse, que al igual que acontece en los seguros de responsabilidad civil por ocurrencia, a pesar de haberse configurado

88 CHUBB DE COLOMBIA COMPAÑÍA DE SEGUROS S.A. Op. Cit. "14. Notificación y Comunicación. (...)Así mismo, si durante el Período de Vigencia de la Póliza o el Periodo Adicional de Notificación (según este se establece en la carátula de las CONDICIONES PARTICULARES de esta Póliza y en el numerales 7, 8 y 9 de las CONDICIONES GENERALES de esta Póliza), el Tomador del Seguro, el Grupo Corporativo y/o los Asegurados adquieren conocimiento o noticia de hechos o circunstancias que pudieran razonablemente dar lugar a un Reclamo, y comunican tales hechos o circunstancias por escrito al Asegurador durante el Periodo de Vigencia de la Póliza o el Período Adicional de Notificación, entonces, cualquier Reclamo resultante de tales hechos o circunstancias será considerado como si hubiese sido presentado durante el Período de Vigencia de la Póliza o el Periodo Adicional de Notificación en el que dichos hechos o circunstancias fueron comunicadas al Asegurador por primera vez.". 
el siniestro y de existir amparo por parte de la aseguradora, de no verificarse posteriormente una efectiva reclamación de perjuicios por parte de la víctima al asegurado o su asegurador nunca se concretará o se hará líquida la obligación indemnización a cargo de la compañía de seguros.

Una segunda posible solución, parte de la premisa fundamental que no sería técnico ni admisible equiparar el reporte de circunstancias conocidas a la reclamación o siniestro mismo. Lo anterior, porque no resulta acertado calificar el aviso o reporte al asegurador de un hecho o circunstancia conocida como una reclamación, menos aún, cuando ello implicaría establecer ese momento como punto generador de un siniestro amparado por el seguro de responsabilidad civil.

Bajo esta línea de interpretación, el siniestro naturalmente seguiría siendo la reclamación misma, que, en este caso en particular, podría en forma excepcional verificarse incluso con posterioridad a la expiración de la vigencia de la póliza. Por consiguiente, un lógico entender de la cláusula de aviso o notificación de hechos o circunstancias conocidas en materia de seguros bajo la modalidad "claims made", debería conducir a que se concluyera que dicho aviso no es el siniestro mismo, sino únicamente una anticipación o principio de amparo, una marcación o señalamiento de una póliza o vigencia del seguro que se podría verse afectada a futuro, incluso si la reclamación se produjese en forma extemporánea, circunstancia que podría concretarse o no, dependiendo exclusivamente de la voluntad de la víctima.

Sin perjuicio del partido que se tome por una u otra interpretación, lo verdaderamente relevante es que ningún término prescriptivo en contra del asegurador pueda empezar a correr antes de que se produzca la efectiva reclamación por parte de la víctima al asegurado o al asegurador de su responsabilidad civil. Resultaría totalmente antitécnico afirmar que a partir de la notificación o aviso al asegurador del hecho conocido empiezan a correr los términos extintivos de las acciones procedentes contra la compañía de seguros. Situación que sería en extremo absurda, especialmente para el asegurado, quien no tendría nada concreto que reclamarle al asegurador hasta tanto la víctima accione contra él. De cara a la víctima beneficiaria del seguro sería igualmente improcedente que en un seguro bajo la modalidad "claims made" se hubiera podido configurar un siniestro y de paso prescrito la obligación indemnizatoria a cargo de la aseguradora, antes de tan siquiera haber presentado su reclamación. 
En criterio de este autor cualquier opción que se acoja produce un resultado válido siempre y cuando se respete el principio innegociable de que el cómputo de prescripción en contra del asegurado no empezará a correr hasta tanto se verifique una reclamación por parte de la víctima. Quizás puede ser más sencillo, en aras de evitar el debate sobre el inicio del término de prescripción, acoger la segunda teoría pues con ella se deja salvedad de que el siniestro aún no se ha producido y simplemente lo que hay es una anticipación provisional o principio de amparo a favor del asegurado en caso de que fuese requerida la efectiva protección a futuro.

\subsection{Cláusula de unidad de reclamo}

Pasando a otro tema, las pólizas suelen establecer en su definición de reclamo la figura que se denomina como unidad de evento y que tiene como finalidad considerar como un solo evento o reclamo, todas aquellas reclamaciones que se deriven o tengan causa $u$ origen en un mismo acto incorrecto. Con dicho pacto lo que se pretende es que la totalidad de los reclamos relacionados entre sí que reciba el administrador, sin importar el momento en que se le formulen, sean atendidos bajo la póliza vigente al momento en que se conoció/recibió la primera reclamación, circunstancia que no es de poca monta por cuanto representa variadas repercusiones en lo que respecta al límite y/o sublímites contratados y, por supuesto, a los deducibles acordados ${ }^{89}$.

La mencionada figura de unidad de evento a veces es pactada con diferentes nombres y denominaciones, por ejemplo, Seguros Suramericana ${ }^{90}$ consagra en la sección tercera de su clausulado una cláusula

89 ACE SEGUROS DE COLOMBIA S.A. Op.Cit. “4. LIMITE DE RESPONSABILIDAD: El límite de responsabilidad máximo del Asegurador por toda Pérdida amparada por la presente póliza, será aquel señalado en las Condiciones Particulares. Las Costas forman parte de la Pérdida y en tal virtud están sujetas al límite de responsabilidad establecido para la Pérdida. El Asegurador no pagará Costas en exceso al límite máximo de responsabilidad señalado en las Condiciones Particulares. Todas las Reclamaciones derivadas del mismo Acto negligente o Culpa se considerarán como una sola Reclamación, la cual estará sujeta a un único límite de responsabilidad. Dicha Reclamación se considerará presentada por primera vez en la fecha en que la primera del conjunto de las Reclamaciones haya sido presentada, sin importar si tal fecha tuvo lugar durante o con anterioridad al inicio del Periodo Contractual. En consecuencia, constituirá una sola y única Pérdida la serie de Actos Negligentes o Culpas originados de una misma Reclamación, con independencia del número de reclamantes y Reclamaciones formuladas. La responsabilidad máxima del Asegurador dicha Pérdida, incluyendo las Costas, no excederá el límite de responsabilidad por evento establecido en las Condiciones Particulares." (Subraya por fuera del texto original).

90 SEGUROS GENERALES SURAMERICANA S.A. Op. Cit. 
denominada Límite máximo de indemnización, que cumple el mismo propósito anterior, en los siguientes términos:

"La responsabilidad máxima de SURAMERICANA de indemnizar los daños y perjuicios causados por los Asegurados cuya causa sea un mismo Siniestro, incluyendo los gastos de defensa en procesos judiciales y demás egresos amparados bajo la presente póliza, no excederá del límite de cobertura por evento establecido en las condiciones particulares de la póliza. Así mismo, la responsabilidad máxima de SURAMERICANA respecto de los daños y perjuicios generados por todos los eventos reclamados durante la vigencia de la póliza, incluido el Periodo Adicional para Notificaciones, será el monto fijado en las condiciones particulares de la póliza con carácter de límite agregado anual de la cobertura correspondiente a la vigencia respectiva. De presentarse más de una reclamación que involucre el mismo acto incorrecto o actos incorrectos interrelacionados se considerará que todas ellas constituyen una sola reclamación y, así mismo, que dicho acto incorrecto o actos incorrectos han tenido lugar en el primero de los siguientes momentos: - El momento en que se hace por primera vez una reclamación que involucre el mismo acto incorrecto o actos incorrectos interrelacionados o, - el momento en que la reclamación que involucre un mismo acto incorrecto o actos incorrectos interrelacionados deba considerarse hecha, según los términos de la cláusula $3 b$ de la sección V Condiciones Generales de esta póliza”.

Un problema que se ha generado en la práctica con esta loable cláusula de unidad de reclamos, especialmente en las pólizas de servidores públicos, se presenta cuando se inician investigaciones en contra un funcionario asegurado, luego se cierran y, posteriormente al no haber cosa juzgada, se reanudan haciendo alusión a los mismos hechos que fueron inicialmente investigados, ocasionando que al recibir nuevamente la reclamación fundada en los mismos hechos por parte del mismo asegurado, las compañías de seguros puedan, dependiendo del tiempo trascurrido, alegar la prescripción extintiva del derecho a percibir la indemnización, lo cual si bien se ajusta a derecho, no parece muy equitativo de cara a los intereses del asegurado.

\subsection{Momento en el que se verifica el siniestro - notificación de la reclamación al asegurado.}

Por último, con relación a la configuración del siniestro en el seguro de responsabilidad civil bajo la modalidad "claims made", es importante preguntarse cuándo exactamente se verifica el siniestro, en tratándose por ejemplo de procesos judiciales, en los cuales se presenta demanda contra el asegurado. Las pólizas no son explícitas, ni precisas en indicar 
si el momento exacto de la reclamación estará definido por la presentación de la demanda ante el juez, la admisión de esta por parte del funcionario judicial o, precisamente, la notificación del auto admisorio de la demanda al administrador asegurado.

Establecer con precisión dicho momento no es de poca monta, por cuanto, entre la fecha de presentación de la demanda y su notificación al demandado pueden trascurrir varios meses, situación que sin lugar a dudas podría significar la expiración de una vigencia del seguro y el inicio de otra nueva o, quizás, la finalización de una vigencia y la ausencia de cobertura para el futuro por no renovación del mismo.

Lo más apropiado sería considerar como fecha de configuración de la reclamación la correspondiente al momento de notificación de la demanda, lo anterior porque lo más lógico es que se tome como siniestro esa manifestación externa que sea conocida por el asegurado y, también, porque las pólizas para otro tipo de procesos, investigaciones y reclamación prejudiciales sí toman como fecha precisa de configuración del siniestro el momento en que se notifica o informa al administrador asegurado el reclamo formulado.

\section{PRESCRIPCIÓN DE LA OBLIGACIÓN INDEMNIZATORIA EN LOS SEGUROS “CLAIMS MADE" O POR RECLAMACIÓN}

Cuando se hace referencia a seguros de responsabilidad civil es menester diferenciar tres distintas acciones que pudieran estar presentes cuando se produjese un evento dañoso del que se generó obligación de indemnizar perjuicios. Concretamente, se hace referencia primero a las acciones en cabeza de la víctima derivadas de las normas generales del derecho de la responsabilidad civil contractual o extracontractual para reclamar su indemnización al civilmente responsable. Dichas acciones se regirán por su respectivo sistema de prescripción no siendo aplicables a ellas las normas del contrato de seguros.

En segunda medida se hace referencia a las acciones derivadas del contrato de seguro mismo o de la ley que lo rige. En el seguro de responsabilidad civil por expreso mandato normativo, artículo $1133^{91} \mathrm{del}$

91 CÓDIGO DE COMERCIO. "Artículo 1133. Acción directa contra el asegurador. <Artículo subrogado por el artículo 87 de la Ley 45 de 1990. El nuevo texto es el siguiente:> En el seguro de responsabilidad civil los damnificados tienen acción directa contra el asegurador. Para acreditar su derecho ante el asegurador de acuerdo con al artículo 1077, la víctima en ejercicio de la acción directa 
Código de Comercio, existe una acción directa en cabeza de la víctima, beneficiaria legal de dicho seguro, para solicitarle directamente a la aseguradora, la indemnización de aquellos perjuicios que le fueron causados por el asegurado.

Como tercera y última posibilidad, igualmente derivada del contrato de seguro, habrá cabida a una acción a favor del asegurado, civilmente responsable, para solicitarle al asegurador el rembolso o indemnizaciones de las erogaciones por las que el mismo fuera responsable ante la víctima, denominada por algunos doctrinantes como acción indirecta.

En lo que respecta a la prescripción extintiva correspondiente a las acciones que se desprenden del contrato de seguro de responsabilidad civil y de la normatividad que lo rige, serán dos normas fundamentales del Código de Comercio las que deberán utilizarse para resolver todos los posibles supuestos, los artículos $1081^{92}$ y $1131^{93}$.

La primera norma, de aplicación genérica para todos los tipos y clases de seguros, consagra dos sistemas diferentes de prescripción, uno denominado ordinario de corte eminentemente subjetivo, porque operará pasados dos años desde que el interesado haya conocido o debido conocer el nacimiento del derecho a su favor y, el otro, denominado extraordinario de estirpe objetiva, porque se verificará trascurrido un término de cinco años desde el nacimiento del derecho o del hecho que diere lugar a la acción, sin importar para el efecto que el interesado hubiere tenido o no conocimiento del mismo.

La segunda, exclusiva para el contrato de seguro de responsabilidad civil indica que los términos prescriptivos previstos en el artículo 1081 del Código de Comercio empezarán a correr para la víctima a partir del acaecimiento del hecho externo dañoso y, para el asegurado en contra

podrá en un solo proceso demostrar la responsabilidad del asegurado y demandar la indemnización del asegurador".

92 CÓDIGO DE COMERCIO: "Artículo 1081. Prescripción de acciones. La prescripción de las acciones que se derivan del contrato de seguro o de las disposiciones que lo rigen podrá ser ordinaria o extraordinaria. La prescripción ordinaria será de dos años y empezará a correr desde el momento en que el interesado haya tenido o debido tener conocimiento del hecho que da base a la acción. La prescripción extraordinaria será de cinco años, correrá contra toda clase de personas y empezará a contarse desde el momento en que nace el respectivo derecho. Estos términos no pueden ser modificados por las partes".

93 CÓDIGO DE COMERCIO. "Artículo 1131. Ocurrencia del siniestro. <Artículo subrogado por el artículo 86 de la Ley 45 de 1990. El nuevo texto es el siguiente:> En el seguro de responsabilidad se entenderá ocurrido el siniestro en el momento en que acaezca el hecho externo imputable al asegurado, fecha a partir de la cual correrá la prescripción respecto de la víctima. Frente al asegurado ello ocurrirá desde cuando la víctima le formula la petición judicial o extrajudicial". 
de su asegurador, a partir del momento en que el tercero le reclame judicial o extrajudicialmente su responsabilidad.

Como novedad normativa la ley 1564 de 2012 en su artículo 9494, consagró en materia de procedimiento civil que la prescripción podrá interrumpirse civilmente además de con la presentación y notificación de la demanda, mediante una reclamación por escrito presentada al deudor, interrupción que solo podrá surtirse por una vez. Lo cual, de llegar aceptarse que es aplicable también en materia de seguros, tema que no será objeto de este estudio, implicaría un notable cambio con un gran impacto práctico que sin lugar a dudas podría aliviar un poco, en materia del seguro de responsabilidad, la penosa realidad que obligaba siempre al asegurado a demandar a su asegurador para interrumpir el término de prescripción de la acción derivada del contrato de seguro, única posibilidad civil existente hasta la fecha.

Debe reconocerse que el tema de la prescripción nunca ha sido una asignatura pacífica en la que se haya logrado un consenso entre los expertos en seguros, ni que tampoco es el propósito de estas líneas agotar en extenso el estudio de la prescripción en el seguro de responsabilidad bajo todas sus modalidades. Se intentará por ello, simplemente, hacer una breve referencia a cómo opera dicha institución exclusivamente en lo que atañe al seguro de responsabilidad civil bajo la modalidad de cobertura "claims made" o por reclamación.

\subsection{Prescripción de las acciones a favor del asegurado y del beneficiario del seguro de responsabilidad civil en contra de la aseguradora bajo el sistema "claims made"}

Puede empezarse afirmando que las normas antes citadas fueron diseñadas y expedidas para regular el seguro de responsabilidad civil clásico que operaba únicamente bajo la modalidad de "ocurrencia pura". Y que el texto actual del artículo 1131 fue proferido en 1990 mucho antes de la expedición de la Ley 389 de 1997.

El uso y aplicación de la norma del año noventa no parece tener mucho sentido ni cabida para el novedoso esquema "claims made", pues en lo que tiene que ver con el término prescriptivo de la acción

94 LEY 1564 DE 2012. “Artículo 94. Interrupción de la prescripción, inoperancia de la caducidad y constitución en mora. La presentación de la demanda interrumpe el término para la prescripción e impide que se produzca la caducidad siempre que el auto admisorio de aquella o el mandamiento 
directa consagrada a favor de la víctima contra el asegurador, a todas luces sería ilógico que siendo el detonante de la cobertura otorgada, es decir el siniestro mismo, la reclamación presentada por la víctima al asegurado o directamente al asegurador, pudiera empezar a contarse el término prescriptivo de la acción directa a favor del beneficiario desde el acaecimiento del hecho externo imputable al asegurado, hecho evidentemente anterior a la configuración del siniestro bajo la modalidad "claims made".

Tal contrasentido llevaría al equívoco de pensar y concluir que empezaría a correr el término prescriptivo de un derecho, que en estricto sentido, aún no ha nacido, pues bien debe recordarse que es diferente el vínculo que existe entre la víctima y el civilmente responsable, de la relación que existirá entre la víctima beneficiaria del seguro y el asegurador que ampara la responsabilidad civil de su asegurado, puesto que para que hubiese responsabilidad civil basta que se hubiese producido un daño imputable a un sujeto, pero para que exista cobertura por parte de un seguro de responsabilidad civil, no solo es necesario ello, sino también que se verifiquen las condiciones establecidas en el contrato de seguro, siendo la principal de ellas que se hubiere elevado una reclamación en contra del asegurado.

Con relación al término prescriptivo de las acciones en contra del asegurador en el seguro de responsabilidad civil bajo la modalidad por reclamación se ha pronunciado la doctrina patria en varias ocasiones.

Primero el profesor Juan Manuel Díaz-Granados ${ }^{95}$ afirmó:

“(...) el riesgo asegurable en modalidad se circunscribe a la reclamación, la cual obviamente habrá de presentarse durante la vigencia. En consecuencia, la noción de siniestro de responsabilidad igualmente cambia, a pesar de la

ejecutivo se notifique al demandado dentro del término de un (1) año contado a partir del día siguiente a la notificación de tales providencias al demandante. Pasado este término, los mencionados efectos solo se producirán con la notificación al demandado. La notificación del auto admisorio de la demanda o del mandamiento ejecutivo produce el efecto del requerimiento judicial para constituir en mora al deudor, cuando la ley lo exija para tal fin, y la notificación de la cesión del crédito, si no se hubiere efectuado antes. Los efectos de la mora solo se producirán a partir de la notificación. La notificación del auto que declara abierto el proceso de sucesión a los asignatarios, también constituye requerimiento judicial para constituir en mora de declarar si aceptan o repudian la asignación que se les hubiere deferido. Si fueren varios los demandados y existiere entre ellos litisconsorcio facultativo, los efectos de la notificación a los que se refiere este articulo se surtirán para cada uno separadamente, salvo norma sustancial o procesal en contrario. Si el litisconsorcio fuere necesario será indispensable la notificación a todos ellos para que se surtan dichos efectos. El término de prescripción también se interrumpe por el requerimiento escrito realizado al deudor directamente por el acreedor. Este requerimiento solo podrá hacerse por una vez." (Subraya por fuera del texto original) 
contradicción que se genera frente al artículo 1131 del Código de Comercio, el cual dispone que el siniestro, se entenderá ocurrido, cuando acaezca el hecho externo imputable al asegurado. Este precepto debe entenderse en su versión original para la modalidad de ocurrencia, ya explicada; pero para la nueva modalidad de reclamación existe una norma especial y posterior cuya aplicación prevalece cuando los contratantes acuerden la reclamación como esquema. La congruencia exige que un concepto se considere siniestro tanto para exigir que el fenómeno se presente durante la vigencia como para efectos de la prescripción. (...) No tendría ninguna lógica decir que para la primera es la reclamación y para la segunda es la ocurrencia del hecho o viceversa.

Gústenos o no, la ley establece una figura en la cual el riesgo-y por lo mismo el siniestro - es la reclamación para todos los efectos. En consecuencia, el artículo 1131 habrá de interpretarse armónicamente con la nueva Ley 389 de 1997, de manera que la prescripción operará así: Respecto de la víctima, la prescripción iniciará su cómputo desde la reclamación, que es el siniestro en esta modalidad y que debe presentarse durante la vigencia. No se computará desde la ocurrencia del hecho, dado que no es el siniestro y, de hacerlo, probablemente por ser anterior puede consumarse la prescripción previamente a la reclamación, lo cual es una conclusión absurda. Respecto del asegurado, no se presenta ninguna inquietud, ya que tanto en la modalidad de ocurrencia como en la de reclamación la prescripción corre desde el momento de la reclamación de la víctima”.

\section{La anterior posición fue posteriormente refrendada y apoyada por el profesor Carlos Ignacio Jaramillo ${ }^{96}$ en las siguientes líneas:}

"Como lo hemos ya expresado, a nuestro juicio este artículo 1131 fue modificado, parcial y tácitamente, por el artículo $4^{\circ}$ de la Ley 389 de 1997, norma posterior y especial, amén de incompatible, genética y funcionalmente, con el sistema prohijado por esta disposición de 1990, predicable del que hemos llamado sistema tradicional, por oposición al extraordinario (claims made). De ahi que frente a la víctima, en puridad, la prescripción en este novísimo esquema debe comenzar a correr a partir de la reclamación y no del '[...] hecho externo imputable al asegurado', se insiste, porque cuando se estructuró este artículo (1990), el sistema en comentario no tenía aún carta de ciudadanía legal, lo que aconteció más de un lustro después. En tal caso la reclamación, de cara a las llamadas cláusulas claims made, sería el punto de partida de la prescripción, tanto para la víctima, como para el asegurado, respecto al asegurador, lo cual, tiene un sentido uniformador".

No cabe dudas que para llegar a conclusiones lógicas, en necesario armonizar las normas en comento con la nueva modalidad "claims made" para poder concluir, si bien no de forma totalmente pacífica e inequívoca que, la prescripción de la acción a favor del asegurado en

96 JARAMILLO. Derecho de Seguros. t. II. Op.Cit. p. 379 - 380. 
contra de su asegurador empezará a correr desde el momento en que haya conocido o debido conocer la reclamación indemnizatoria de perjuicios por parte de la víctima, momento a partir del cual empezará a correr igualmente el término de prescripción ordinario de dos años para solicitar al asegurador el pago del siniestro. En el momento de la reclamación del tercero al asegurado se verificará, tanto el acaecimiento del siniestro como el punto de partida de la exigibilidad de la obligación del asegurador ante el asegurado. Naturalmente siendo una reclamación un hecho visible, palpable, notorio lo normal es que siempre aplique el término ordinario de prescripción previsto en el artículo 1.081 del Código de Comercio y no sea necesario recurrir al sistema extraordinario.

En lo que atañe a la prescripción de la acción directa de la víctima en contra del asegurador, debemos concluir que siendo el siniestro en materia de "claims made" la reclamación misma, será el actuar de la víctima, reclamando ora al civilmente responsable, ora al asegurador de dicha responsabilidad, el que detone la cobertura conferida. Es decir, es la conducta misma de la víctima la que configura y realiza tanto, el acaecimiento del siniestro, como el inicio del cómputo prescriptivo de la acción directa en contra del asegurador.

En otras palabras, debe concluirse que, en materia de seguros de responsabilidad civil por reclamación, la acción directa consagrada por el artículo 1133 del Código de Comercio a favor de la víctima, se torna prácticamente imprescriptible pues es exclusivamente, el actuar de la víctima el que marca el inicio del cómputo extintivo. Lo anterior será la regla general en materia de cobertura bajo la modalidad "claims made", salvo en aquellos eventos en los que el perjudicado optare únicamente por solicitar la indemnización de los perjuicios sufridos al asegurado civilmente responsable, evento en el cual iniciaría el cómputo de un término prescriptivo (ordinario o extraordinario según la posición doctrinal o jurisprudencial que se quiera adoptar ${ }^{97}$ ) para reclamarle de manera directa al asegurador, la satisfacción de las pérdidas sufridas.

97 Debe tenerse presente al respecto que hay jurisprudencia de la Corte Suprema en la que se afirma que como protección de la víctima es lógico que el término prescriptivo de la acción directa en contra del asegurador sea de cinco años y no de dos, dado que no es sencillo tener fácil acceso y conocimiento a la existencia de un seguro de responsabilidad civil y tampoco a la identidad de la aseguradora. CORTE SUPREMA DE JUSTICIA. Sentencia del 29 de junio de 2007 con Ponencia de Carlos Ignacio Jaramillo Jaramillo. Expediente No 11001-31-03-009-1998-04690-01. 


\subsection{El cómputo del término prescriptivo en los eventos en que se hubiese efectuado la notificación de hechos y circunstancias que podrian derivar en una reclamación futura}

Para finalizar el estudio del fenómeno prescriptivo es indispensable revisar cómo deberían correr los términos extintivos en aquellos eventos en los cuales los clausulados, existentes en el mercado, consagran que se entenderá como una reclamación, el simple aviso o notificación al asegurador de hechos y circunstancias conocidas durante la vigencia de la póliza cuando de las mismas se pudiere razonablemente deducir o inferir que se producirá una reclamación futura.

Como fue analizado líneas atrás, la configuración del siniestro cuando opere dicha prerrogativa de los seguros de responsabilidad bajo la modalidad cliams made puede ser entendida de dos formas distintas. La primera de ellas, según indicamos, implicaría considerar que la notificación o aviso de hechos y circunstancias conocidas al asegurador será equivalente a una reclamación efectiva, lo que en otras palabras implicaría que el aviso o reporte de dichos hechos sería el detonante de la cobertura ofrecida, es decir el siniestro mismo.

La segunda alternativa, como fue también visto, sería considerar que el reporte de hechos conocidos al asegurador no equivale a una reclamación, sino simplemente se trata de una prerrogativa consignada en las pólizas bajo la modalidad "claims made" que permite anticipar el amparo o cobertura, señalando o marcando como afectada una póliza específica, sin perjuicio de que el siniestro mismo se configure posteriormente, cuando tenga lugar una real reclamación basada en dichos hechos contra el asegurado o su asegurador.

El aviso al asegurador de un hecho o circunstancia permitirá que una póliza que funciona bajo la modalidad "claims made" tenga inmediatamente efectos prospectivos y pueda por ende dar amparo a una reclamación que ocurra con posterioridad al vencimiento de dicho seguro. Tal circunstancia, impedirá que se produzcan vacíos de cobertura por cuanto tales hechos conocidos de los cuales se pudiere inferir que tendrá lugar una futura reclamación se encuentran excluidos de cobertura en vigencias posteriores del seguro tal y como se analizó al estudiar dicha exclusión.

Sin perjuicio, de la interpretación que se adopte, lo cierto es que el cómputo de la prescripción y concretamente las reglas contenidas en los 
artículos 1.081 y 1.131 del Código de Comercio deberán aplicarse de manera armónica con el propósito de no incurrir en absurdos o generar notables injusticias.

De tal suerte, si se define que el aviso o notificación de hecho relevantes conocidos al asegurador configura el siniestro mismo, deberá darse aplicación al artículo 1.131 para considerar que para el asegurado el cómputo de prescripción de su acción contra el asegurador no empezará correr hasta tanto no reciba una reclamación judicial o extrajudicial de parte de la víctima solicitándole la indemnización de los perjuicios causados. De cara a la víctima será muy difícil determinar cuál sería el momento en el que iniciará el cómputo de la prescripción, pues no parecería acertado que se considerase como punto de inicio de la prescripción en su contra un hecho que le es totalmente ajeno y que, por supuesto desconoce, como lo sería el aviso o notificación de un hecho o circunstancia conocida que haga el asegurado a su asegurador.

Las dos únicas opciones posibles serían considerar como punto de partida el momento en que ocurrió el hecho dañoso imputable al asegurado, como lo indica el artículo 1.131 posición que se antoja bastante razonable y quizás acertada o por el contrario tomar como punto de inicio el momento en que la víctima presente la reclamación al asegurado o al asegurador, momento que es uniformemente empleado para los seguros que funcionen bajo la modalidad de cobertura "claims made".

En aras de la coherencia de criterios se anticipa que sería más equitativo y acertado afirmar que bajo esta tesis debería darse plena aplicación al artículo 1.131 del Código de Comercio, iniciando por tanto el cómputo de prescripción contra el asegurador, para el asegurado cuando reciba reclamación judicial o extrajudicial y para la víctima desde el acaecimiento u ocurrencia del hecho externo dañoso imputable al asegurado.

De otra parte, en caso de que se considere que el aviso o notificación de hechos y circunstancias relevantes al asegurador no configura un siniestro como tal, sino simplemente es un señalamiento o marcación de una póliza que se podría afectar a futuro, la prescripción de la acción en cabeza del asegurado contra su asegurador deberá empezar a contar desde el momento en que recibe la reclamación, que por cierto será el momento mismo en que efectivamente acaezca el siniestro. Para la víctima, siendo el siniestro su reclamación ante el asegurado o su asegurador, nuevamente será menester sostener, que su reclamación 
o petición contra cualquiera de éstos será la que marque el inicio de la prescripción de su acción contra el asegurador.

Tal y como se había anticipado líneas atrás, por su practicidad y por su fidelidad en aras de preservar la identidad y naturaleza de las cláusulas "claims made" se considera que tiene mejor sustento y solidez adoptar la segunda solución o alternativa ofrecida y considerar que la notificación o aviso al asegurador de hechos y circunstancias conocidas, no es en sí misma una reclamación y no configura la verificación de un siniestro en los seguros de responsabilidad bajo la modalidad por reclamación, sino únicamente una anticipación provisional de cobertura para evitar injustos vacíos en contra del asegurado, protección provisional que por supuesto no se consolidará, ni trascenderá si no se verifica una efectiva reclamación por parte de la víctima.

\section{BIBLIOGRAFÍA}

Barrera Tapias, Carlos Darío. La prescripción de las acciones derivadas del seguro de responsabilidad civil. (Ley 389/97). En: Memorias del XXI Encuentro Nacional - Nuevas orientaciones del contrato de seguro en Colombia y en América Latina. Acoldese - Editorial Guadalupe. 1998.

Botero Morales, Bernardo. La teoría y la práctica del seguro por reclamación o seguro claims made. Ponencia presentada En: $1^{\circ}$ Congreso Internacional de Derecho de Seguros: La Protección del Consumidor y el Seguro de Responsabilidad Civil. Cartagena de Indias, marzo 22 y 23 de 2012. s.n.; s.p.i.

"Prescripción del derecho a la indemnización en el seguro por reclamación o claims made". En Derecho de Seguros y Reaseguros, Líber Amicorum en homenaje al profesor Arturo Díaz Bravo. Pontificia Universidad Javeriana Grupo Editorial Ibáñez, 2015. P.

\section{Centro de arbitraje y conciliación Cámara de Comercio de Bogotá}

Laudo Arbitral Proyectar Valores S.A. Comisionista de Bolsa en Liquidación forzosa administrativa contra Cubb de Colombia Compañía de Seguros S.A. y Chartis Seguros Colombia S.A. (2977) Centro de Arbitraje y Conciliación de la Cámara de Comercio de Bogotá. Árbitros: Carmenza Mejía Martínez; Juan Carlos Esguerra Portocarrero y Juan Manuel Díaz-Granados

\section{Corte Suprema de Justicia. Sala Casación Civil}

Sentencia del 10 de febrero de 2005, expediente 7614. 
Sentencia del 15 de diciembre de 2.006. M.P. Jaime Alberto Arrubla Paucar. Exp. 52001-31-03-004-2000-00276-01.

Sentencia del 29 de junio de 2007 con Ponencia de Carlos Ignacio Jaramillo Jaramillo. Expediente $\mathrm{N}^{\circ}$ 11001-31-03-009-1998-04690-01.

Sentencia del 18 de diciembre de 2013. MP Fernando Giraldo Gutiérrez. Rad. N ${ }^{\circ}$ 11000131030412000-01098-01.

Sentencia del 31 de julio de 2014. MP Ruth Marina Díaz. Rad. № 110001-3103-0152008-00102-01

Díaz-Granados Ortíz, Juan Manuel. El seguro de responsabilidad. Bogotá D.C. Editorial Universidad del Rosario y Pontificia Universidad Javeriana, Facultad de Ciencias Jurídicas. $2^{\circ}$ Edición. 2012.

DonAti, Antígono. Los seguros privados. Barcelona. Bosch.1960.

Fernández del Moral Domínguez, José. El seguro de responsabilidad civil de administradores y altos directivos de la sociedad anónima (Póliza D\&O) Granada. Editorial COMARES. 1998.

Garrigues, Joaquín. Contrato de Seguro Terrestre. Segunda edición. Madrid. Imprenta Aguirre. 1983.

IsAza Posse, María CRISTINA. “Ámbito temporal de la cobertura y prescripción en el seguro de responsabilidad civil" En: Revista Ibero-Latinoamericana de Seguros. Volumen 22. Año 2005. Bogotá D.C. JAVERGRAF- Pontificia Universidad Javeriana.

Jaramillo Jaramillo, Carlos Ignacio. Derecho de Seguros. Tomo II. Bogotá D.C., Editorial Temis S.A.- Pontificia Universidad Javeriana. 2011.

Martínez Cárdenas, Betty Mercedes. Buena fe en la interpretación del contrato de seguro. En: Realidades y Tendencias del Derecho en el Siglo XXI. Derecho Privado. Tomo IV Volumen 1. Bogotá. Editorial Temis S.A. - Pontificia Universidad Javeriana. 2010.

Miranda SuÁrez, Francisco. Seguro de responsabilidad civil por mal praxis médica. Delimitación temporal de la cobertura del Seguro. En: Revista Ibero-Latinoamericana de Seguros. Número 16 de 2001. Bogotá D.C. JAVERGRAF- Pontificia Universidad Javeriana.

MúÑoz LaVerde, Sergio. El principio de buena fe y su incidencia en la interpretación del contrato. Nulidad de las cláusulas abusivas en el derecho colombiano. En: Realidades y Tendencias del Derecho en el Siglo XXI. Derecho Privado. Tomo IV Volumen 1. Bogotá. Editorial Temis S.A. - Pontificia Universidad Javeriana. 2.010 . 
Narváez Bonnet, Jorge Eduardo. El Contrato de Seguro en el Sector Financiero. Grupo Editorial Ibáñez. Tercera Edición. 2014.

Ordóñez Ordónez, AndrÉs E. El contrato de seguro. La ley 389 y 1997 y otros estudios. Bogotá D.C. Universidad Externado de Colombia. 1998.

Ossa Gómez, J. Efrén. Teoría General del Seguro - El Contrato. Segunda edición actualizada. Bogotá D.C. Editorial Temis S.A. 1991. 663 páginas.

Pavelek Zamora, Eduardo. Delimitación temporal en el seguro de responsabilidad civil la nulidad del "claims made" ¿otra vuelta a la tuerca? En: Gerencia de Riesgos, núm., 41. Fundación Mapfre Estudios. 1993.

Roncero SÁnChEZ, ANTONIO. El seguro de responsabilidad civil de los administradores de una sociedad anónima. En: Revista InDret. Barcelona. Nº 2 de 2.004. Páginas. 3 a 38. ISSN 1698-739X. http://www.indret.com/es/

Sánchez Calero, Fernando. El seguro de responsabilidad civil para administradores, directores, y gerentes de las sociedades mercantiles. En: Revista Ibero-Latinoamericana de Seguros. Volumen 17. Bogotá. D.C. JAVERGRAF- Pontificia Universidad Javeriana. 2.002.

La delimitación temporal del riesgo en el seguro de responsabilidad civil tras la modificación del artículo 73 de la Ley de contrato de seguro" En: Revista Española de Seguros, núm. 89, de 1997. p. 14.

Sobrino, Waldo Augusto. Seguros y responsabilidad civil. Buenos Aires. Editorial Universidad. 2.003.

Solarte Rodríguez, Arturo. La buena fe contractual y los deberes secundarios de conducta. En Revista Vniversitas $\mathrm{N}^{\circ} 108$ de diciembre de 2004. Bogotá. Editorial JAVERGRAF - Pontificia Universidad Javeriana. 2004.

Stiglitz, RubÉn. Temas Derecho de Seguros Bogotá. Grupo Editorial Ibáñez-Pontificia Universidad Javeriana. 2010.

Uribe LozadA, Nicolás. Régimen general de responsabilidad civil de los administradores de sociedades y su aseguramiento. Universidad Javeriana. Grupo Editorial Ibáñez. 2013.

Zornosa Prieto, Hilda. Los problemas de interpretación de la prescripción en el seguro de responsabilidad civil en la legislación colombiana bajo el sistema claims made. En: Escritos sobre riesgos y seguros. Universidad Externado de Colombia. 2012. 